\title{
The Icelandic power structure revisited
}

\author{
Gunnar Helgi Kristinsson, Professor of political science, University of \\ Iceland
}

\begin{abstract}
Political scientists have developed three main interpretations of the Icelandic power structure - namely, traditional elitism, competitive elitism and professional pluralism. These can be seen to some extent as successive regimes, with traditional elitism prevalent in the nineteenth century, competitive elitism for much of the twentieth century and professional pluralism in more recent decades. However, their relative strength at different times, and the extent to which they still predominate, remains uncertain. This article evaluates how the different models reflect on the position of the political elite over time and how helpful they are in understanding contemporary power structures. Data on the composition of the political elite on one hand, and eight contemporary elite groups on the other are analysed in order to evaluate elite openness, elite selection and network patterns. The results provide support for conventional interpretations, in that competitive elitism replaced traditional elitism in important respects during the twentieth century, but has itself been replaced in many respects by professional pluralism. Accordingly, professional pluralism is characteristic of the contemporary power structure, with relatively open access to elite groups, strong influence of meritocratic and professional criteria and network patterns which are concentrated within, rather than across, spheres of influence. Remnants of traditional elite privilege and competitive elitism, where political parties play a central role, can be found in a number of areas, and professional pluralism has important elitist features.
\end{abstract}

Keywords: Power structure; elites; Iceland.

Icelandic Review of Politics and Administration. Vol. 14, Issue 1. Special issue on power and democracy in Iceland (1-34) (c) 2018 Contact: Gunnar Helgi Kristinsson, ghk@hi.is

Article first published online May $31^{\text {st }} 2018$ on http://www.irpa.is

Publisher: Institute of Public Administration and Politics, Gimli, Sæmundargötu 1, 101 Reykjavík, Iceland

Stjórnmál \& stjórnsýsla. 1. tbl. 14. árg. 2018. Sérhefti um vald og lýđræđi á Íslandi (1-34) Fræđigreinar

(c) 2018 Tengiliður: Gunnar Helgi Kristinsson, ghk@hi.is

Vefbirting 31. maí 2018 - Birtist á vefnum http://www.irpa.is

Útgefandi: Stofnun stjórnsýslufræđa og stjórnmála, Gimli, Sæmundargötu 1, 101 Reykjavík

DOI: https://doi.org/10.13177/irpa.a.2018.14.1.1

This work is licensed under a Creative Commons Attribution 3.0 License. 


\section{Introduction}

During the mid-1990s, Keith Dowding (1996 ix) noted that the great power debate on elitism and pluralism had run out of steam, as he put it 'with both sides apparently thinking they had won'. With regard to theoretical innovations, this is probably an apt description, although a number of authors have continued producing high quality and innovative work in this area (e.g. Best \& Higley 2010). Empirical studies on individual elites and elite structures remain relatively common, indicating the continuing relevance of elite research, despite the controversy concerning their overall political influence. The Nordic countries, with the exception of Iceland, have held on to the ambition of conducting comprehensive research on elites and elite structures at the societal level in a series of power studies (see in particular Christiansen et al. 2001; Peterson et al. 1990; Ruostetsaari 2015; Østerud et al. 2004). While a certain amount of variation may be observed among countries, the overall picture is one of relative openness and (except in Finland) declining cohesiveness (e.g. Christiansen et al. 2001; Ruostetsaari 2007).

Corresponding research on Iceland is lacking. Although the idea of an Icelandic power study has been entertained now and then since the 1980s, it has failed to win government support. This means that Iceland lags very much behind the other countries with regard to research on the power structure, including Icelandic elites. Important questions concerning elite openness, elite recruitment and cohesiveness remain uncovered by empirical research. Therefore, it is the purpose of the present paper to step into that void with data obtained in a power and democracy project funded by the University of Iceland in 2015. The paper begins with an overview of previous theorizing about political elites in Iceland, which serves as the point of departure for the study of the historical development of the political elite and the contemporary patterns of elite openness, recruitment and connectedness. On the basis of the major models that emerge from this discussion, expectations are developed with regard to the main characteristics of the Icelandic elite structure. This is followed by a short section on the data and then the presentation of the main results concerning elite openness, selection principles and network patterns.

\section{Previous research}

Despite the absence of a major power study project, the Icelandic power structure has been a central subject in Icelandic political science since its inception at the University of Iceland in the early 1970s. The first international journal publication by an Icelandic political scientist was Grímsson's (1976) 'The Icelandic Power Structure 1800-2000', where he broad-brushed the main features of the power structure in the nineteenth and twentieth centuries. Numerous subsequent studies have been devoted to aspects of the power structure. A review of this literature can only be attempted in the most tentative terms in the present context, but the main features are rather striking. Three models of elite power in Iceland stand out, each with roots in different schools of theorizing about power and power elites - namely, traditional elitism, competitive elitism and professional pluralism. Each model is anchored in international theorizing on the subject, including 


\section{STJÓRNSÝSLA}

elitism (Higley \& Pakulski 2012), democratic elitism (Best \& Higley 2010) and neopluralism (Dunleavy \& O'Leary 1987). Traditional elitism, characterized by closed and interconnected elites based on social position, was predominant during the nineteenth century and the first decades of the twentieth century. This was followed by a variant of the democratic elitist model, which may be termed competitive elitism, during the midtwentieth century, where party elites and their competition for power put their marks on many different spheres of society, with a tendency to politicize administration, culture and the economy. During the last decades of the twentieth century and into the twentyfirst century, the established power structure has been increasingly challenged by greater pluralist or neo-pluralist features, which we term professional pluralism, characterized by greater separation of elites according to the sphere of activity, and professionalization at the expense of politicization.

The economic crash in 2008 once again placed elite versus popular power at the forefront of public debate. The crash fuelled political distrust and spread perceptions of corruption (Vilhelmsdóttir et al. 2015; Erlingsson et al. 2016). Radical proposals for constitutional change were partly directed against the established power structure, including party elites. Elites are increasingly the subject of political rhetoric and the suspects in critical commentary. Thus, the question of what kind of elite structure prevails and how it affects the quality of government remains highly relevant.

Power studies in political science face important conceptual and methodological challenges. Power, according to Lukes (1974), is an 'essentially contested concept' without broad consensus on its definition or method. Beyond overt conflict (the one-dimensional view), power may be applied through agenda control (the two-dimensional view) and through influence over subjective perceptions of interests (three-dimensional view). In all cases, however, power seems to imply 'the production of intended effects' (Russel 1938; see also Wrong 1995). What is 'intended', however, may not always be obvious and, in some cases, the effects may be produced as much by luck as by effort (Dowding 1996). The operationalization of the concept in empirical research, therefore, remains problematic.

Control over resources is an essential prerequisite for power. To bring about desired results, individuals and organizations need financial means, knowledge, organization, contacts and other resources. However, control over resources may not be sufficient to bring about the desired effects, and various other factors (including luck) may affect outcomes. The study of how resources are distributed is therefore relevant, but is not, strictly speaking, the same as studying power, at least not all of its aspects. As resources are, to a significant extent, unevenly divided - as they are in all advanced societies - we can study aspects of this distribution as a power structure. This does not imply that studying the distribution of resources is the only way to study power. A decision-making approach is an equally feasible and possibly complementary way of studying power or aspects of power. A plausible assumption, however, is that resources affect decisionmaking outcomes. 


\section{Three power structure models}

Elite studies in Iceland have produced three main models, partly reflecting different theoretical traditions and also the different time-frames of the research. Traditional elitism is concerned with the division between elite and non-elite and influenced by the works of the classical elitists (including Mosca 1939; Pareto 1961; Michels 1962). It regards the elite as highly exclusive and autonomous. Competitive elitism is concerned with the competition for power among elite groups, in particular through party competition. Influential authors in this tradition include Weber (1968) and Schumpeter (1976) (see also Held 1996). Elites, according to this view, compete for power across different spheres, with political parties playing a leading role. In contrast, professional pluralism is less concerned with the competition between elites than their control over separate spheres of activity. It is influenced by the pluralist school of thought, according to which plural elites co-exist in largely separate spheres of society (Dahl 1961; Putnam 1977). The weakening of centralized political control is a concern of some authors writing in this vein (Peters \& Pierre 2004; Dahlström et al. 2011), while others take a more benign view of the effects of limiting majoritarian institutions (Vibert 2007; Cornell \& Lapuente 2014). Professional pluralism is the version of pluralism most relevant to the Icelandic case, according to recent theorizing on the subject. Professional pluralism is an elite structure organized mainly according to professional criteria, with a relatively strong emphasis on professional meritocracy and cohesive professions, but weak inter-elite connections.

Traditional elitism. Traditional elitism has been most strongly advocated in Icelandic political science by Grímsson (1976), especially in his treatment of the nineteenth century and parts of the twentieth century. According to him, Icelandic society during the nineteenth century was characterized by a highly elitist system, where the two major centres of power, the administration and the Church, were ruled by a cohesive elite tied together through bonds of kinship and privilege. Although the system developed some pluralist traits during the second half of the century through the emergence of the Alpingi (Icelandic parliament) in 1845 and the development of a domestic press, the elite remained a closely knit group based on bonds of kinship and school ties. The extension of the franchise and the growing political impact of class-based divisions in the early twentieth century increased the pluralist traits of the system as the established elites of the politics of independence (i.e. pre-1918) faced challenges from the emerging class-based groups. Grímsson argued, however, that as class politics became the predominant feature of the system, from around 1930 to 1950-60, its pluralist features were weakened as a small group of party leaders took control of different spheres of society and strongly influenced the administration, judiciary, interest groups, media, culture and economy.

The dynamic factors contributing to elite power in Iceland, according to Grímsson's analysis, seem to be, above all, kinship ties and educational privileges. The decreasing importance of such ties during the second half of the twentieth century contributed to growing pluralism and, at the time of writing - in 1976 - Grímsson predicted that pluralist traits would be predominant by the turn of the century. 
Although Grímsson presented no systematic evidence to support his case, there seems to be little reason to doubt that the power structure in nineteenth-century Iceland was elitist in many respects. In comparison to other systems, however, it may have been relatively egalitarian. An Icelandic aristocracy, for instance, never existed. Nordal (1994, 100) suggests that there was little difference between the social position of well-to-do farmers and the literati (lardir menn) during the eighteenth and nineteenth centuries and, together, the two formed a relatively closed upper class. Grimsson's account of the twentieth century is more problematic. Many accounts of Icelandic politics during the twentieth century portray it as relatively conflict-ridden compared to the rest of the Nordic region (Jónsson 2014). To group conservatives and communists into a single ruling political elite seems odd. Similarly, the extent to which elite privilege has actually disappeared as a feature of a new pluralist system calls for closer attention. Torfason et al. (2017) indicate that their study on present-day business elites in Iceland reveal 'a layered elite structure and gaps in elite-populace relations' (2).

Competitive elitism. Interpretations of the Icelandic power structure as competitive elitism take as their point of departure the competition between party elites for positions of power and the important rewards that such positions may yield. As in Grímsson's account of mid-twentieth century Icelandic politics, the party elites play a central role, according to this, but they constitute separate and partly hostile elites, rather than a single cohesive group. The Icelandic political parties evolved in the inter-war period as organizations with a great deal of external influence, but relatively elitist internal structures (Kristinsson 1993; Kristjánsson 1993). The old party groups of the period of traditional elitism were replaced during this period by class parties, which combined mass-party organization with a strong element of patronage (Indriðason 2005; Kristinsson 1996; Kristjánsson 1993). Their access to highly valued public positions and services was facilitated by a relatively weak bureaucracy at the national and local levels and the inability of the administration to form a coalition to safeguard bureaucratic autonomy, which was essential for preventing the development of patronage politics in many other places (Shefter 1994).

While the main parties to a great extent shared the dividends of political patronage, privileged access to state power was in most cases a crucial element in the patronage networks of parties and politicians. This encouraged political conflict and competition for power. Minority governments were not tolerated, and a strong emphasis on minimum winning coalitions went hand in hand with ministerial government, where each member of a governing coalition was relatively autonomous in disposing of patronage goods which belonged to their portfolios (Kristinsson \& Indriðason 2007). The political parties were connected to many different spheres of society and controlled the exchange of political support and patronage rewards which fed the system.

Professional pluralism. In the 1960s, there were signs of increasing dissatisfaction with the system of 'party rule' (flokeksredi) (Kristjánsson 1994). Several developments challenged competitive elitism in the following decades. Kristinsson (2012) suggests that four interrelated developments played a role. In the first place, liberalization of the 
economy made the business sector less dependent on political access than before, reducing (but by no means eliminating) the clout of political elites in the economy. Professionalization was a second factor contributing to the reduction of party control, as professional criteria for decision-making in both the public and private sectors - including appointments - increasingly replaced political ones. Furthermore, the media market underwent considerable changes in the last decades of the twentieth century, as stateand party-controlled media increasingly gave way to commercial media. While influential groups still compete for influence over the media, the political parties have lost much of their former control. Finally, the professionalization of politics and campaigning made the parties less dependent on their old clientelist networks than before. The job of a parliamentarian was recognized as a full-time occupation during the 1960s, and during the 1970s, it became rare for members of parliament (MPs) to occupy other positions parallel to working in the Alpingi (Kristjánsson 1994). Running the parties became increasingly costly as professional techniques replaced voluntary work, although the introduction of party primaries around 1970 kept the need for personal contact networks alive (see also Kopecký \& Mair 2012).

While there seems to be little doubt that professionalism and pluralism became increasingly strong characteristics of the Icelandic power structure compared to earlier periods, it remains to be established how far remnants of the older power structures still co-exist with the new one. After all, powerful groups rarely surrender their privileges voluntarily. Thus, important groups from the era of traditional elitism established a strong foothold in the system of competitive elitism through the formation of the Independence Party (IP - Conservative) in 1929 (Guðmundsson 1979). Similarly, party control remains strongly represented at the centres of political power in the Alpingi and cabinet.

In seeking to map contemporary elite structures in Iceland, we make use of a simplified presentation of elite characteristics presented in Table 1.

Table 1. Elite characteristics according to the three elite models

\begin{tabular}{llll}
\hline & Traditional elitism & Competitive elitism & Professional pluralism \\
\hline Openness & Socially exclusive & Politically exclusive & Professionally exclusive \\
Selection principles & High status & Political selection & Professional meritocracy \\
Network patterns & Social networks & Political networks & Professional networks \\
\hline
\end{tabular}

Traditional elitism is socially exclusive, and elites are primarily recruited on the basis of high social status. Such elites are likely to be male and highly dependent on parental status. Although individual rivalries may be prominent, the elite as a whole belongs to the top layers of society. The political elites of competitive elitism are less socially exclusive. A plebeian element is introduced through the competition for popular support and connections to the world of organized interests. Political connections are crucial in the 
world of competitive elitism, and political elites seek to establish control across different spheres of society. Under professional pluralism, by contrast, elites are generally professionally demarcated and separate. They tend to be selected (or self-selected) on the basis of professional merit and may be highly exclusive of non-professionals.

The main task of the present paper is to establish if existing elite models in Iceland are supported by data on elite composition. This means, on one hand, studying the historical trends of elite composition and, on the other hand, devoting special attention to present-day elites. Existing literature leads us to believe that traditional elitism was predominant in the early twentieth century, but was at least partly replaced during the inter-war period by competitive elitism. In recent decades, we expect to see clear signs of professional pluralism. However, the extent to which we should observe remnants of earlier power structures remains uncertain and, to a certain extent, contested.

Our expectations are derived from existing research. With regard to the historical part of our data, we expect to find evidence of traditional elitism (social exclusiveness and high status) in the earliest observations, subsequently giving way to competitive elitism during the mid-twentieth century and professional pluralism as the century drew to an end. In the survey data (obtained in 2015), we expect to find evidence of professional pluralism with professionally exclusive elites, recruitment based on professional merit and a fragmented overall elite structure based on professional clusters.

\section{Data}

Elites are small groups or minorities which are in a position to influence important outcomes by virtue of control over resources. By adopting this approach, we follow in the footsteps of the Danish power study, in which the focus was on power as capacity, rather than its exercise. Christiansen et al. (2001) justify their strategy not by claiming that the resources are more important than other power-related phenomena but that they are often likely to be a 'reasonably good indicator of the actual exercise of power' (12).

The positional method seems to have become the standard approach for studying elites (Hoffmann-Lange 2006, 4). This method has been used in all the Nordic power studies (e.g. Christiansen et al. 2001, 13; Petersson et al. 1990, 309). The Nordic elite studies differ in their data collection methods, with surveys and interviews playing a key role in the Norwegian, Swedish and Finnish cases, while the Danish study was based on the coding of existing information. The present study relies on two main sources of data. One is historical. Several attempts have been made to map Icelandic elites in the twentieth century, in particular politicians (e.g. Kristjánsson 1994) and officials (Kristinsson 1994). In addition to this, we have gathered biographical information on Icelandic MPs from the period 1917-2016. Further, we have used existing sources, including the Alpingi web, several reference books and obituaries, to code information on their backgrounds and careers. ${ }^{1}$

The second source is a survey of eight present-day elites, conducted in 2015. Using a research design influenced by the Nordic power studies, we divide the groups in a similar manner, following the Danish example, more precisely (Christiansen et al. 2001) 
of dividing elites into eight groups - the political, administrative, judicial, organizational, business, media, academic and cultural elites. The eight elite groups were identified following similar criteria as those used in the Danish elite study of 2001 (Christiansen et al. 2001). The political elite was identified as MPs, ministers and other leading members of the political parties. The administrative elite was defined as senior ministry officials, heads of public agencies and top executives of the largest municipalities. The judicial elite comprise Supreme Court judges and chairs of municipal courts. The organizational elite consists mainly of leading persons from the sectoral and labour market organizations. The business elite includes the directors of larger companies and chairmen as well as senior officers of the very largest ones. The media elite consists of editors and senior executives as well as known media personalities. The academic elite consists of university directors and influential scientists (academic impact). The cultural elite comprises chief administrators and influential artists in major fields. Special advice (reputational method) was obtained for mapping the media, academic and cultural elites from strategically placed individuals. For each of the elites, we seek information on how distinct they are (exclusiveness), how people get to become 'members' (selection criteria) and to what extent they actually function as interconnected groups of people (network connections). A highly elitist structure is likely to be characterized by a high degree of exclusiveness, narrowly conceived selection criteria and a high degree of interconnectedness.

Members of the elites were asked to participate in a survey concerning their backgrounds, careers and networks.

Table 2. Response rate for a survey among elites, 2015

\begin{tabular}{llll}
\hline Elite & Members & Respondents & Response rate (\%) \\
\hline Political & 73 & 54 & 74.0 \\
Administrative & 254 & 119 & 46.9 \\
Judicial & 19 & 11 & 57.9 \\
Organizational & 126 & 64 & 50.8 \\
Business & 140 & 62 & 44.3 \\
Media & 79 & 42 & 54.1 \\
Academic & 66 & 51 & 77.3 \\
Cultural & 89 & 50 & 56.2 \\
\hline Total & 846 & 453 & 53.5 \\
\hline
\end{tabular}

According to this 2015 estimate, the Icelandic elites comprise 846 individuals. They are smaller than the Scandinavian ones, which typically total around 2,000 persons, according to the power studies (Christiansen et al. 2001; Peterson 1990), and much smaller than estimates for larger countries (e.g. around 5,000 in Australia, France and Germany and over 10,000 in the United States, according to Best \& Higley 2010, 6-7). While we followed the methods used by the Danish power study closely, we obtained an elite just 
under half the size of the Danish one in a society numbering approximately $6 \%$ of the Danish population. We have no way of measuring the accuracy of our elite definition. We can only note that there may be a tendency for elites to be relatively larger in smaller societies - which fits the notion that the social distance between those in power and the public is often small in smaller societies (Corbet 2015).

The overall response rate for the survey was $53.5 \%$, ranging from $44.3 \%$ in the case of the business elite to $77.3 \%$ among the academic elite. In the following analysis, we treat the judicial and administrative elites as a single group in order to avoid problems related to the small size of the judicial elite. This may affect the analysis of the administrative elite slightly, but the two are similar in many respects.

\section{Elite openness and ascriptive status}

An important method for assessing elite openness is to consider ascriptive status, which refers to those aspects of a person's social position which - unlike achieved status - are determined more or less at birth. In a closed elite system, gender and parental status are likely to affect people's chances of achieving elite positions. In an open system, by contrast, such factors are of smaller importance, although in highly meritocratic systems, there may exist relationships between parental status and offspring performance as well. Such relationships, however, should be relatively modest in open systems, and higher in closed ones. In the present context, we seek evidence of elite openness with regard to social exclusiveness, gender and professional exclusiveness.

Social exclusiveness. In the absence of more complete information, we use paternal education as an indicator of social exclusiveness. This probably works quite well for the

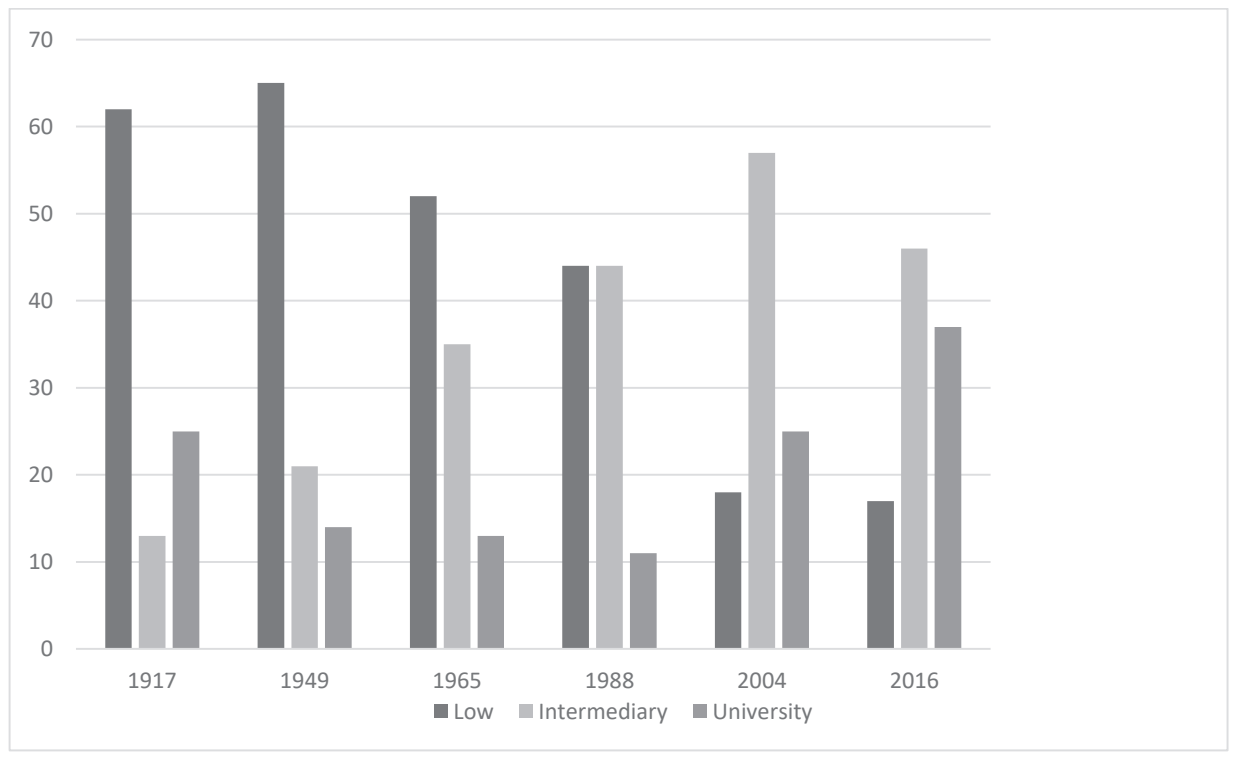

Graph 1. Openness of political elites: Paternal education (\% of elite groups) 
early years, when paternal status more or less determined that of the family. In more recent years, maternal education may, in some cases, complicate things, but on the whole, we are confident that paternal education captures the essential features of ascriptive social status. First, we look at the historical development of the political elite.

At the beginning of the period, MPs are mostly the sons of either farmers or officials. A careful reading of the material indicates that although the composition of the Alpingi in 1917 was biased towards the upper echelons of society, there was, considering the elitist model, a surprisingly large number of self-made men, who had risen from modest origins. Being a member of the Alpingi, nonetheless, was not something any member of society could afford. It was by no means a full-time occupation, and members of the assembly had to have flexible incomes and working hours. During the second half of the twentieth century, the share of those coming from less educated homes declined, while the share of those with intermediary education increased. The share of MPs coming from a university-educated paternal background does not begin to increase again until after the turn of the century.

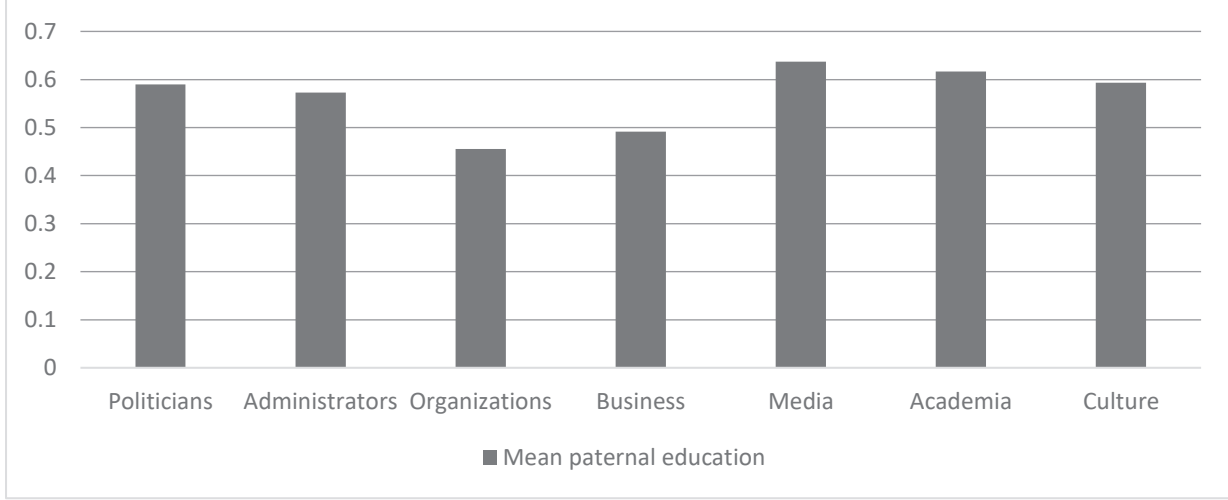

Graph 2. Openness of elites: Mean paternal education of elites in 2015: low $(=0)$ to high $(=1)^{2}$

On the whole, the elites in 2015 do not belong to an exclusive social group, judging by the survey results. Almost a quarter of the elite groups come from families with little paternal education, while just over one third have university (i.e. highly) educated fathers. Yet the greatest number come from a family background of intermediary education. Individuals from the world of organized interests and business score slightly lower than the other groups, but the variations are small overall.

\section{Gender exclusion}

An important dimension of elite exclusiveness concerns gender. Gender is likely to reflect the openness of elite structures, in the sense that more open structures are likely to 
be more accessible to women. Table 5 shows the composition of the Alpingi from 1917 to 2016 with regard to gender.

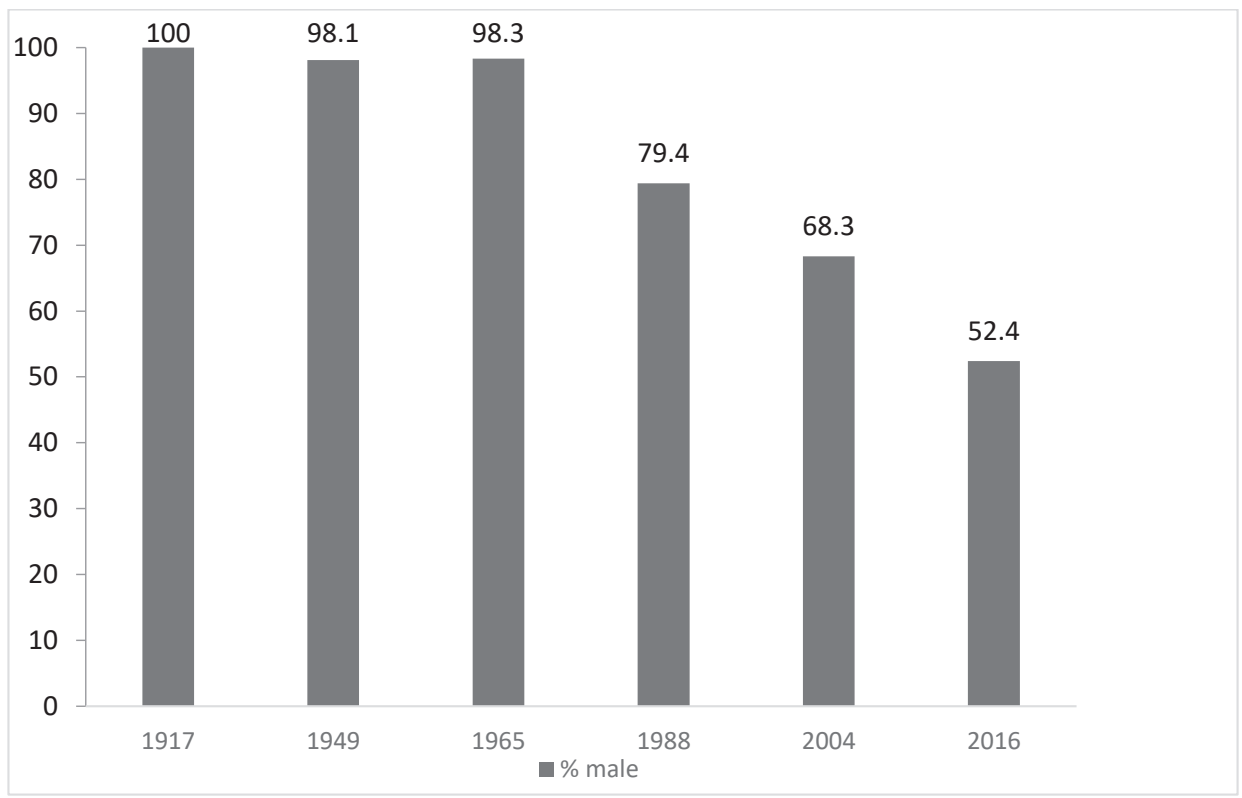

Graph 3. Openness of elites: Gender of MPs, 1917-2016 (\% male)

Although women obtained the right to vote in parliamentary elections in Iceland in 1915, the Alpingi remained male-dominated until relatively recently. At the beginning of this century, the proportion of women had not yet reached one third, although by 2016, it was close to half. According to this, women are close to reaching an equal position to men with regard to political careers, although part of this result has been obtained through the introduction of gender quotas in some political parties. Similar developments at the local level (Kristinsson 2014, 53) indicate, however, that politics no longer remains the exclusive domain of males and has become quite open to members of both sexes.

The survey results indicate that the political and cultural elites are less male-dominated than other elites, although males constitute the majority in both. The economic elite is most heavily dominated by males, followed by the academic elite. When considered together, almost two-thirds of the Icelandic elites consist of males, compared to $35 \%$ females. While this is likely to reflect a considerable improvement in female representation compared to earlier periods, and even a comparatively favourable situation compared to other states, it nonetheless shows that Icelandic elites are not gender neutral. The proportion of women among the Icelandic elites is higher than in the Nordic elite surveys (i.e. $35.3 \%$ compared to $12-26 \%$ ), but the time lag - with the Icelandic one being more recent - may account for some of the difference. The pattern, 


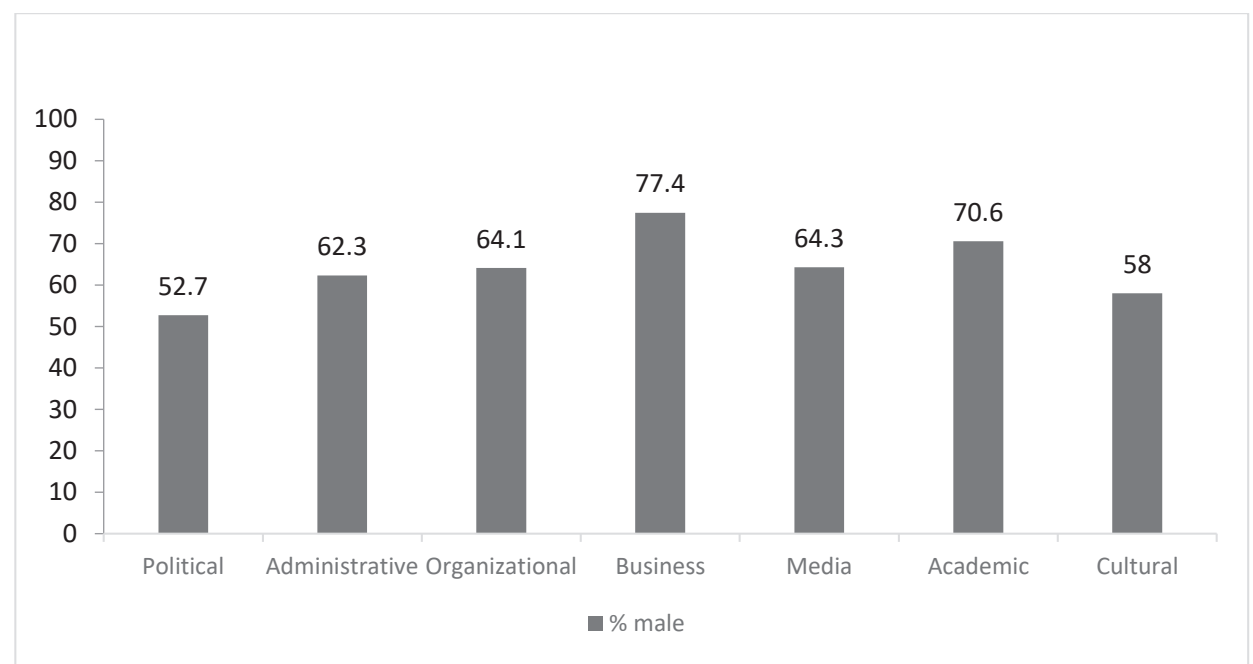

Graph 4. Openness of elites: Gender of Icelandic elites in 2015

however, is broadly similar, in that women in the Nordic countries are best represented in the political elite, followed by the cultural elite, but least in the business elite (Ruostetsaari 2007).

Bearing in mind that the share of women in the Icelandic political elite has improved considerably in recent decades, the question arises if the gender imbalance of Icelandic elites may, to some extent, reflect age and elite renewal. Thus, it seems possible that elite

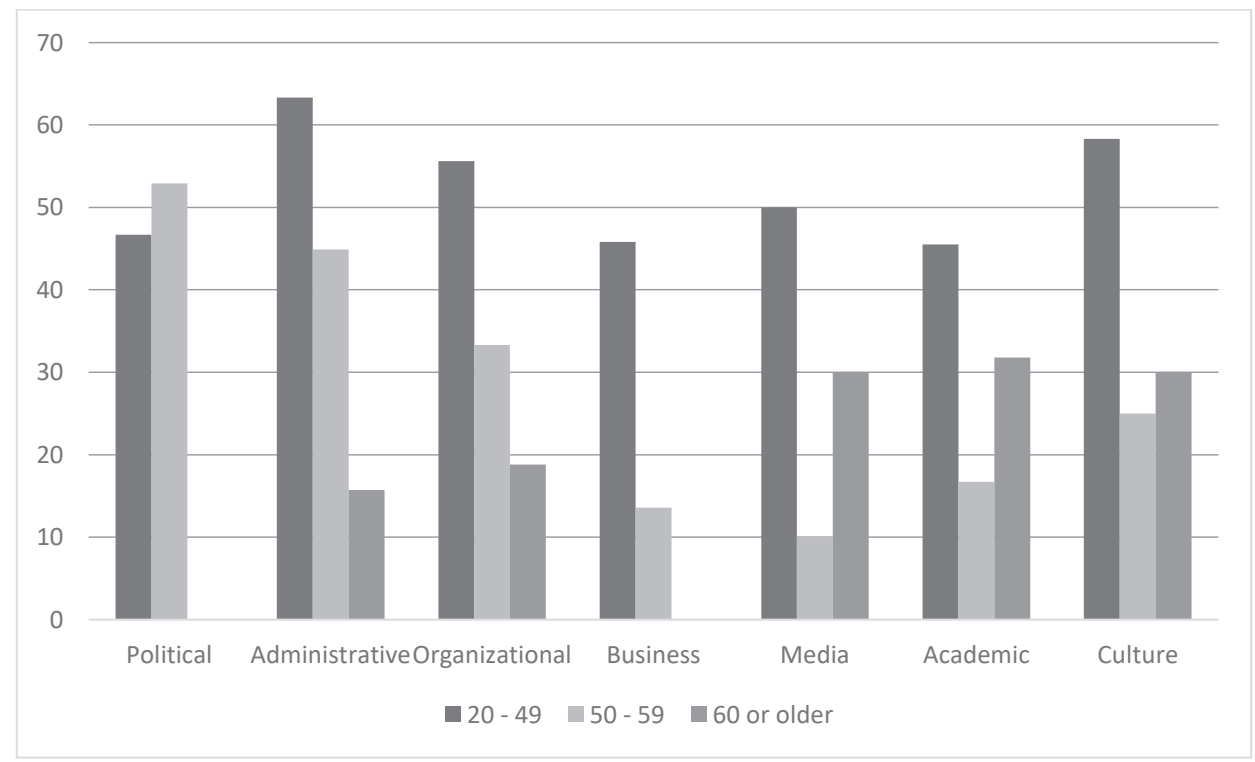

Graph 5. Openness of elites: Female members of Icelandic elites in 2015 by age (\% of age cohort) 
recruitment was more imbalanced two or three decades ago than in recent years, which should be reflected in a greater imbalance among older elite cohorts, and a smaller one among younger ones.

Women represent between $46 \%$ and $63 \%$ of elite members below 50 years across elite groups. This indicates that the system has moved quite swiftly in an egalitarian direction in the last three decades. The major reason for the gender imbalance is maledominated recruitment among older generations. In the age group under 50, women are the majority of the administrative, cultural and organizational elites, while close to half the members of the political, business and academic elites are women. This may indicate that recruitment may already have become quite equal, and a greater gender balance will emerge within a few years. Given the relatively small number of respondents in some cases, the figures should be interpreted with caution.

\section{Professional exclusiveness}

In an open elite system, we should expect parental occupation to be weakly related to elite status. Elites should be accessible to people from different social groups. A certain degree of parental influence, however, is compatible with an open elite structure, in the sense that parents may simply influence the attitudes and motivations of their offspring, rather than opportunities.

In the political sphere, there are well-known examples of 'political families', where MPs are either the sons or daughters of parliamentarians or belong to the same extended family as others who have sat in parliament. Political families or dynasties are a well-known feature of many political systems, and the Icelandic one is no exception. Family ties to other parliamentarians are listed on the Alpingi home page. Our data indicate that in $1917,10 \%$ of members had parents with parliamentary experience, while

Table 3. Paternal careers: \% of respondents in each elite group with fathers working for at least two years in respective fields

\begin{tabular}{llllllll}
\hline & $\begin{array}{l}\text { Political } \\
\text { elite }\end{array}$ & $\begin{array}{l}\text { Administra- } \\
\text { tive elite }\end{array}$ & $\begin{array}{l}\text { Organiz- } \\
\text { ational elite }\end{array}$ & $\begin{array}{l}\text { Business } \\
\text { elite }\end{array}$ & $\begin{array}{l}\text { Media } \\
\text { elite }\end{array}$ & $\begin{array}{l}\text { Academic } \\
\text { elite }\end{array}$ & $\begin{array}{l}\text { Cultural } \\
\text { elite }\end{array}$ \\
\hline Politics & 17.3 & 14.8 & 8.1 & 5.0 & 2.4 & 8.2 & 8.3 \\
Public service & 48.1 & 35.2 & 21.0 & 18.3 & 26.8 & 26.5 & 29.2 \\
Interest groups & 19.2 & 11.7 & 12.9 & 6.7 & 7.3 & 10.2 & 29.2 \\
Private sector & 38.5 & 46.9 & 46.8 & 55.0 & 34.1 & 36.7 & 29.2 \\
Media & 5.8 & 3.1 & 0.0 & 1.7 & 14.6 & 4.1 & 8.3 \\
Academia & 7.7 & 7.8 & 4.8 & 10.0 & 12.2 & 16.3 & 14.6 \\
Culture and arts & 5.8 & 3.1 & 0.0 & 1.7 & 14.6 & 4.1 & 8.3 \\
\hline
\end{tabular}

Note: Figures should be read downwards, but they add up to more than $100 \%$ because more than one career could be mentioned. 
lower figures prevail in subsequent years, ranging from 5\% in 1965 to $9 \%$ in 1988 . In 2016, 6\% of members had parents with parliamentary experience. According to the Danish power study, 10\% of the political elite in 1999 had parents who were politicians (Christiansen et al. 2001, 52). According to Grímsson (1976), family ties were a key ingredient of nineteenth-century Icelandic elitism. While there is still some evidence that family ties matter, there is no evidence that they are among the defining characteristics of the system.

In Table 3, we turn to paternal careers. Table 3 indicates that paternal occupation has some influence on elite composition. The political and administrative elites come disproportionally from a public service environment, and they are also more likely than others to have fathers in politics. The business elite is raised disproportionally in a private-sector environment. The media, academic and cultural elites, similarly, disproportionally have an intelligentsia background. On the whole, however, we see little evidence that the Icelandic elites are closed to new generations or provide strong advantages to their own offspring. The strongest influence is in the business elite, where $55 \%$ have fathers in private-sector occupations. Bearing in mind that the majority of economically active persons belong to the private sector, this is difficult to interpret as a sign of exclusiveness.

The indicators of the openness vs. exclusiveness of Icelandic elites seem to suggest that Iceland, on the whole, is characterized by a relatively open elite structure. Even with regard to gender, where there are still considerable disproportionalities in elite composition, the effect seems to be primarily generational, as the gender ratios are relatively even among younger generations. By comparison with other societies, gender differences in Iceland are probably modest. According to the Global Gender Gap Report 2016, Iceland is the most gender-equal society in the world (World Economic Forum 2016).

\section{Selection principles}

Different systems of elite rule use different types of selection principles. Traditional elitism is based, above all, on social status as a qualifying criterion for elite membership. High social status may pave the way for personal advancement even when it is irrelevant to the position in question. People sometimes enter politics, for example, owing to their high social status, even if they have no relevant background indicating political competence. Under competitive elitism, however, we would expect political experience to be a major selection criterion, along with a proven record of service to the party. It is relevant not only to a political career but to any elite position, given the party political nature of elite competition. Finally, under professional pluralism, we expect relevant educational training and career patterns to be decisive.

\section{Social status}

Social status is a complex phenomenon which, in most cases, can only be measured through proxies. In the present case, we use education as an indicator of social status. Although the two - education and social status - are clearly not the same, education is 
likely to enhance social status, and social status may enhance educational opportunities. The nature of the elite structure may, nonetheless, affect the influence of education on the attainability of elite membership. Both traditional elitism and professional pluralism are likely to emphasize education as a selection criterion for elite membership. In the case of traditional elitism, this may reflect a position of privilege, while under professional pluralism, high educational attainment is closely connected to meritocratic ideals. Competitive elitism, however, is less concerned with academic achievement. Its core selection criterion is party loyalty, which can easily be achieved without academic qualifications.

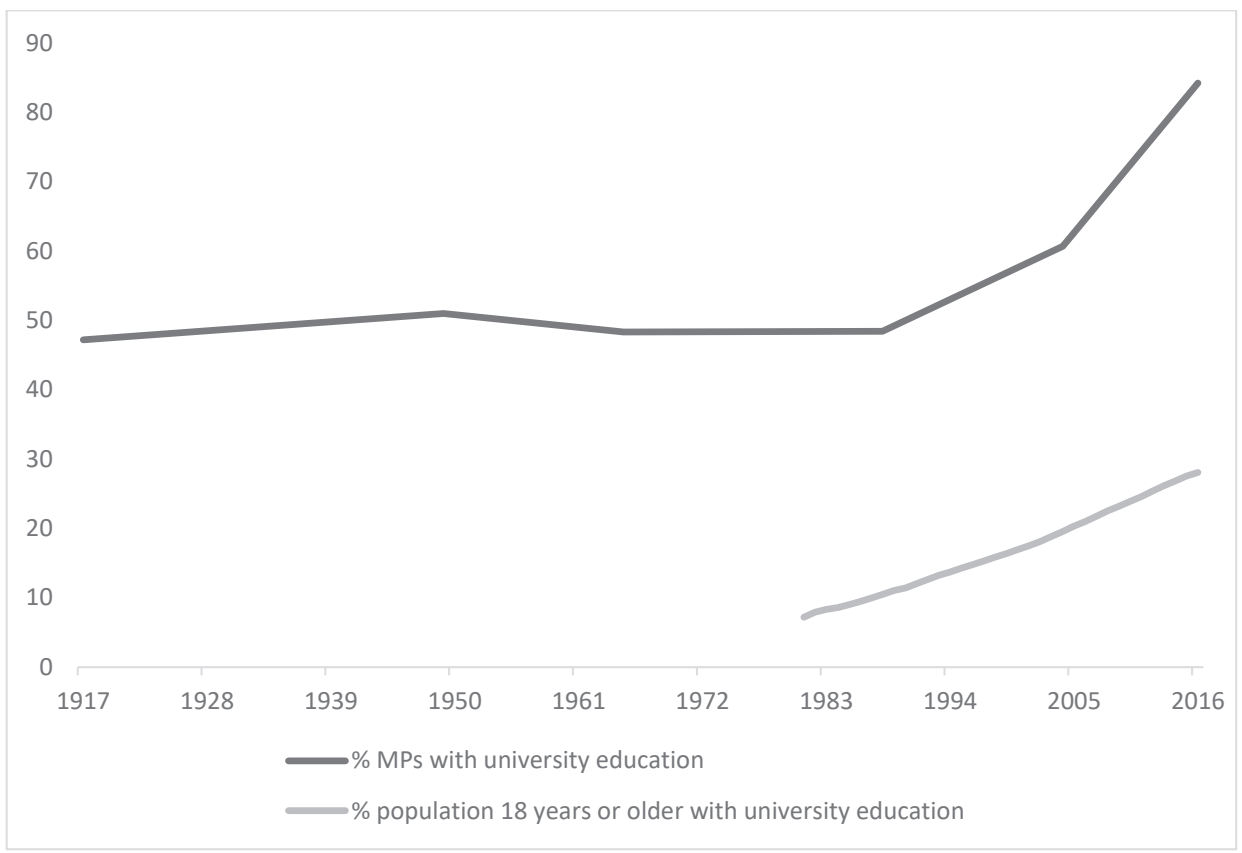

Graph 6. Selection principles: Education of MPs, 1917-2016, and general population 18 years and older, 1981-2016 (\% with university education) ${ }^{3}$

Graph 6 shows several things of interest. First, there are substantial differences between the educational levels of MPs and the general population. Although the two groups are not wholly comparable in age (hardly any between 18 and 23 have a university education), it is quite clear that for much of the twentieth century, the share of the universityeducated population was well below $10 \%$, while among MPs, it hovered around $50 \%$. In all likelihood, the proportion of university graduates among MPs was at least 10 times that of university graduates among the general population. Second, a steep rise in the number of persons with a university education takes place around 1980 among both MPs and the general population. Consequently, the relative advantage of a university education reduced for MPs, from around 10 times as many (or possibly more) with university education to around three times as many. Although this is still a significant 
difference, in relative terms, it indicates a decline in the elite character of MPs as a group with regard to education. Third, the rise in the number of university graduates among politicians indicates the growing importance of university education for a political career, and can thus be seen as an indicator of the growing importance of meritocratic qualifications.

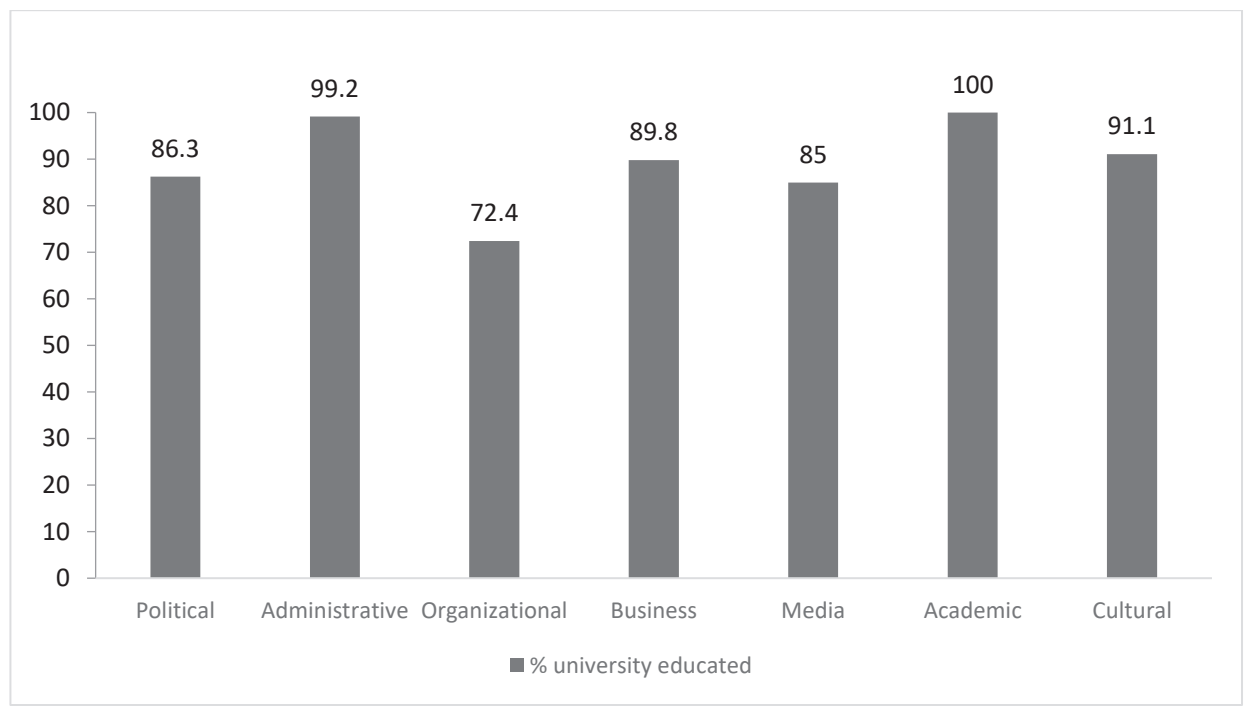

Graph 7. Selection principles: Self-reported education of elites according to the 2015 survey (\% with university degrees)

On average, over $90 \%$ of members of the Icelandic elites are university educated. The only elites among whom university education is not almost universal are the organizational ones, representing a diversity of sectoral and labour-market interests. The academic and administrative elites consist almost exclusively of university graduates, and even the political and media elites are heavily dominated by such groups. This suggests that meritocratic norms are important in the Icelandic elite system. Professional pluralism prevails in this respect.

\section{Political background}

Political background, such as experience of party work or local government, is an important element in competitive elitism. Party work is especially important, as local government is less party political and may reflect broader community status, in line with traditional elitism. Hence, we should expect people with little or no political experience to be prominent in the earlier political elites, while persons with experience of party work should be gaining ground from the mid-twentieth century onwards. During the period of professional pluralism after the turn of the century, political experience becomes less important. The data are presented in Graph 8. 


\section{STJÓRNSÝSLA}

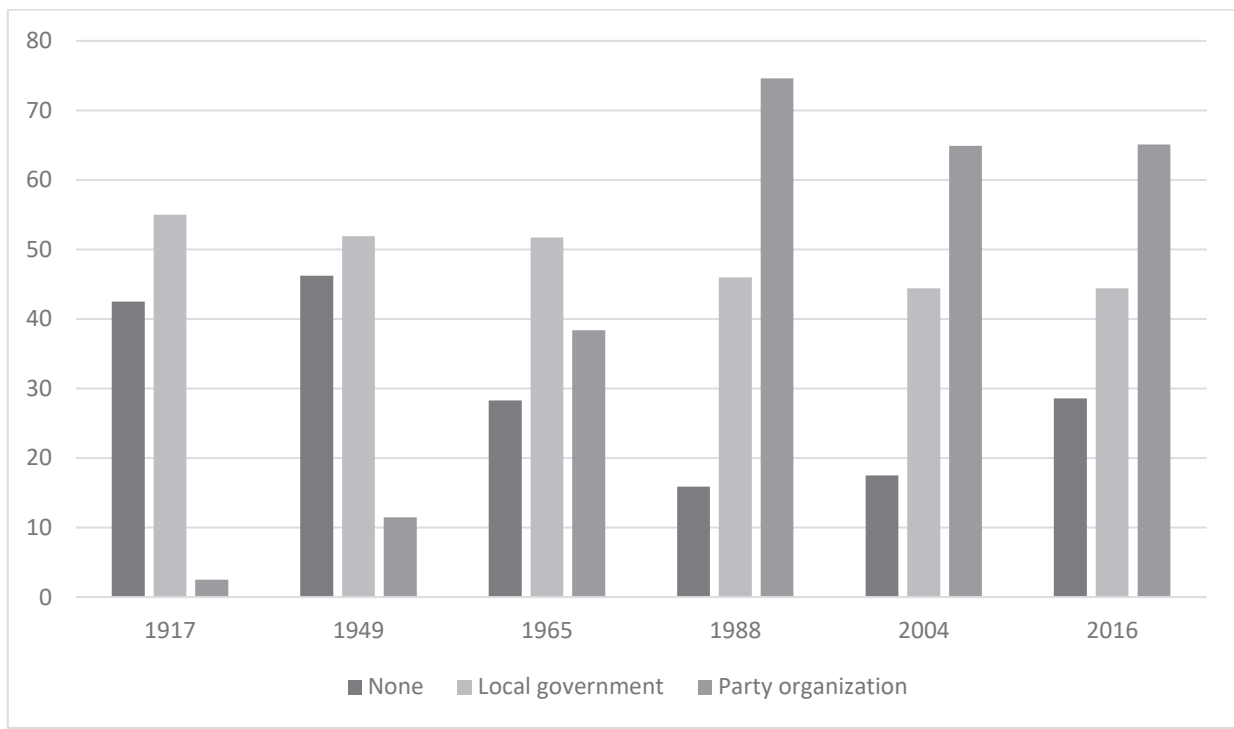

Graph 8. Selection principles: Political background of MPs, 1917-2016 (\% of group with relevant experience [non-cumulative])

The graph shows the proportion of MPs with no known political background prior to entering parliament, those with a background in local government and those who have served representative roles in party organizations. The data seem to partly confirm the

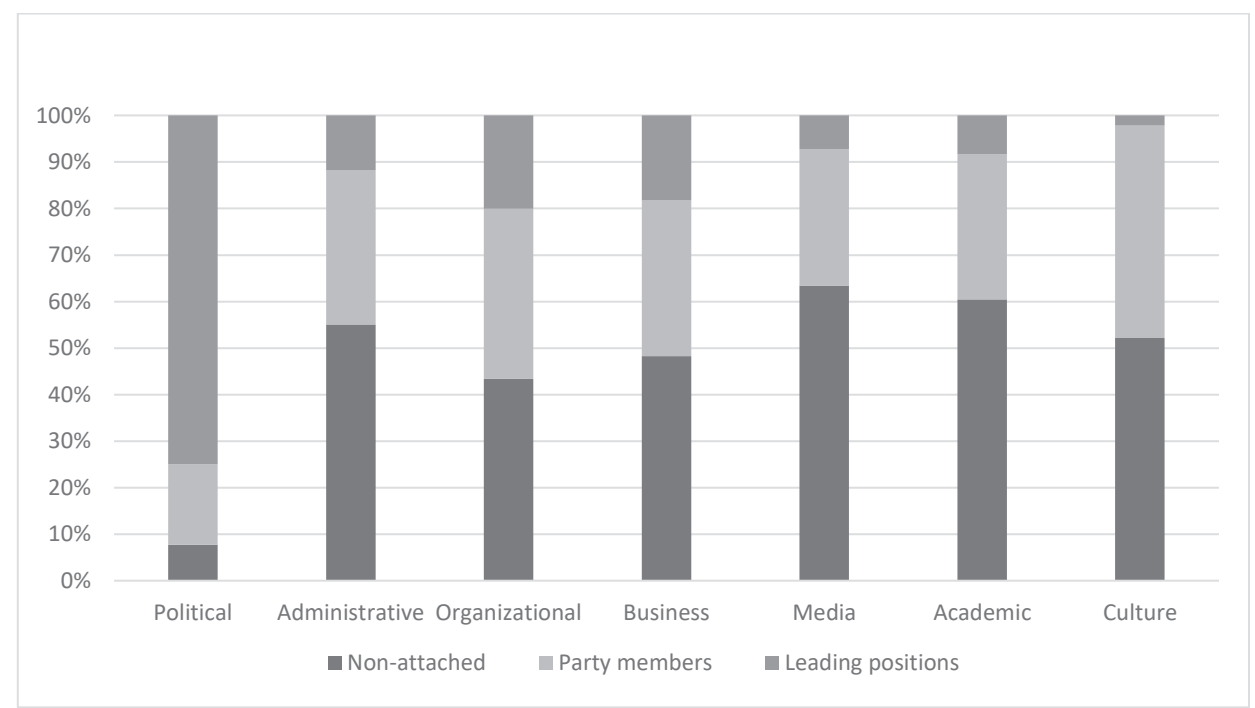

Graph 9. Selection principles: Elite connections to political parties in 2015 (\% of elite groups who have been non-attached to parties, party members or served leading positions in the parties) 
prevalence of traditional elitism at the earliest point, where politicians either had no political connections before entering parliament or can be considered as local dignitaries. The data also reveal the growing significance of political experience from party organizations from the middle of the twentieth century onwards, in line with our expectations based on the competitive elitism perspective. Although the share of persons with party political experience has decreased to a certain extent in 2016, we find that they remain a relatively large proportion of MPs. Despite the emergence of new political movements and an extremely rapid rate of turnover in parliament since 2007, almost two-thirds of MPs have at least some experience of performing a representative role in the party organizations. This is lower than in 1988, but it is still the second-highest proportion in the data. This may indicate that competitive elitism remains an important element in the Icelandic power structure, at least when it comes to the recruitment of political elites.

Apart from the political elite, the organizational and business elites are the most politicized of the elite groups. These groups were, in many ways, the backbone of party support during the heyday of competitive elitism. The private sector was associated with the Independence Party, the Progressive Party (PP - Centre - agrarian), farmers and the co-operative movement, and the left-wing parties competed among themselves and with the Independence Party for leadership in the trade union movement. If we look closer at the respondents who have been members of political parties, we obtain Graph 10.

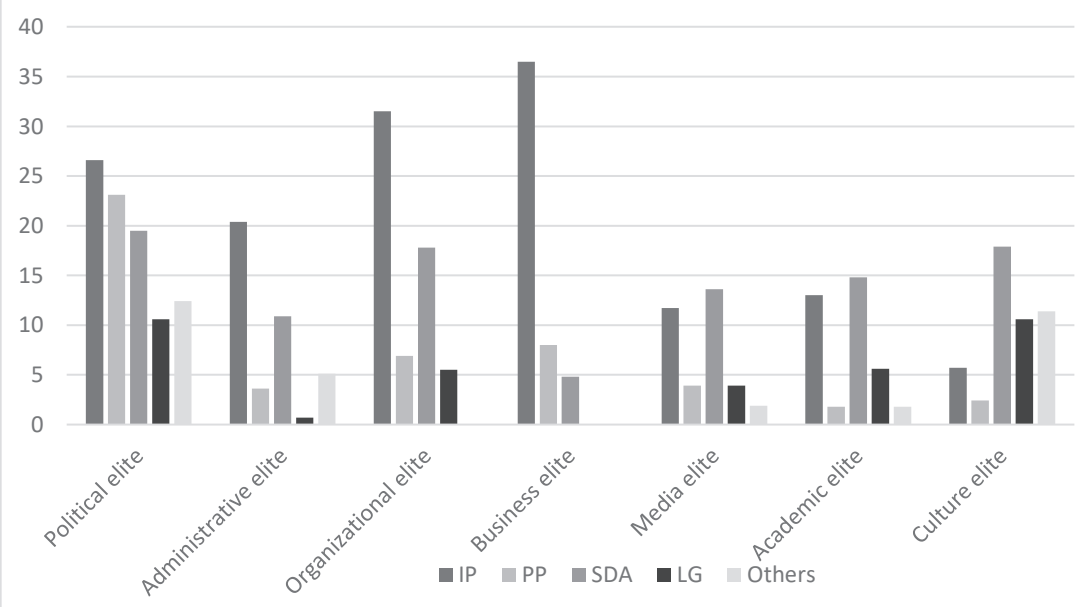

Graph 10. Selection principles: Elite connections to political parties (\% of elite who are/have been party members ${ }^{4}$ )

The only elite group in which all parties are well-represented is the political elite. Others are either highly skewed, such as the administrative, organizational and business elites, or less politicized, such as the media, academic and cultural elites. 
Two of the parties are more closely associated with the elites than others - namely, the Independence Party and the Social Democratic Alliance (SDA - Social Democrats). The Independence Party is very strong among the business elite and well-represented in the organizational, political and administrative elites as well. It is less well-represented in the three elites which may broadly be termed the intelligentsia - that is, the media, academic and cultural elites. Graph 10 gives us reason to believe that IP is the party of the Icelandic establishment, as it is well-represented near the centre of political and economic power, but less well in intellectual and cultural circles. The cultural elite is less a part of the establishment, being more left-wing oriented than the other elites and the only elite apart from the political one where 'others' constitute a substantial proportion of the elite members. Apart from IP, SDA is the only party which can claim a sizeable presence in all the elites, although its share of the business elite is small. The left socialist Left Greens (LG) are weakly represented among elite groups, although stronger among the political and cultural elites than elsewhere.

On the whole, the elites' relationship to political parties indicates that competitive elitism remains a feature of the Icelandic elite system. A large proportion of elite members have some political experience. The majority, however, in the administrative, media, academic and cultural elites have never been registered in a political party. The business and organizational elites are more politicized and both lean towards IP, although a sizeable minority in the organizational elite has belonged to the Social Democrats. Graph 10 indicates that there may be a cultural gap in Icelandic politics between the political and economic establishments, where IP is in a leading position, and the intelligentsia, which is more evenly balanced politically.

\section{Professionalism}

To seek evidence of professionalism among the Icelandic elites, we look for a match between education and careers. Among the political elite, degrees in law and the social sciences have been prominent, with the latter gaining ground in recent decades (a joint share of close to $30 \%$ since the 1960 s), but the former receding somewhat (peaking at $32.8 \%$ in 1965). The share of technical and related subjects has consistently remained close to $20 \%$.

Graph 11 shows the share of different subjects among different elites in 2015. 


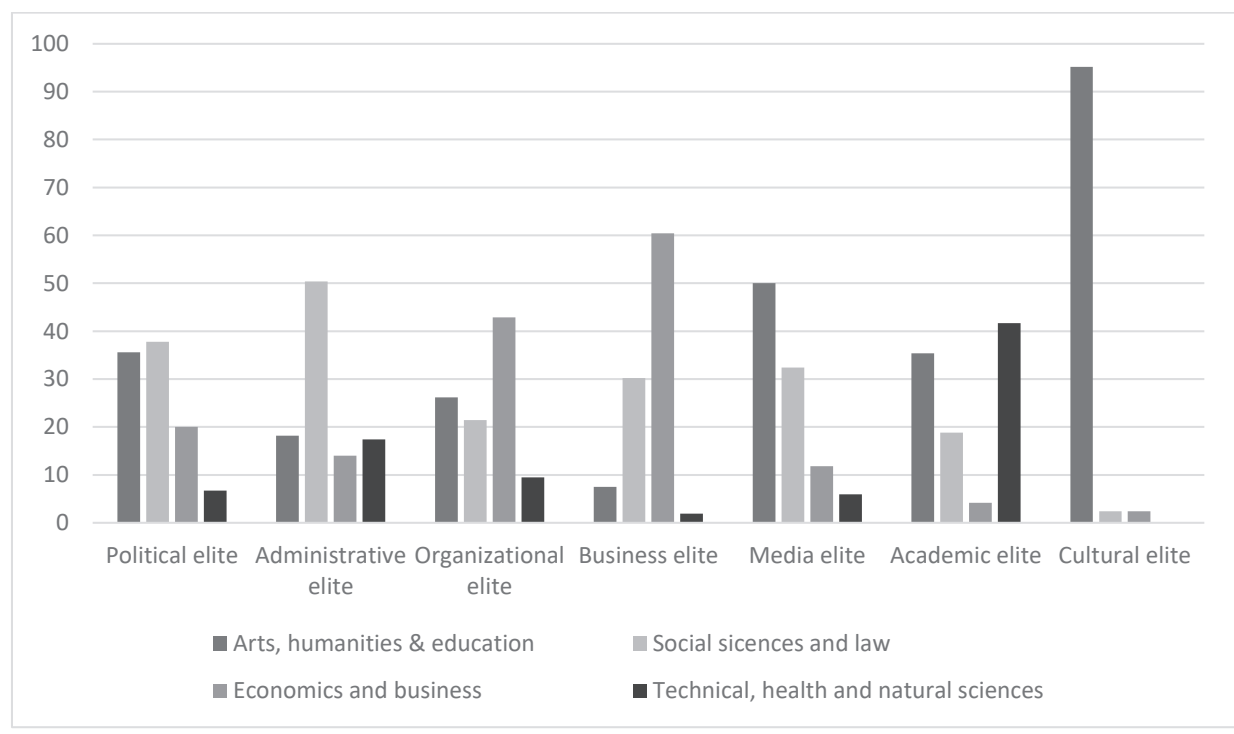

Graph 11. Selection principles: Elite education (\% of subject areas among elite groups)

There are no big surprises in Graph 11. Among the political elite, we find a high share of the social sciences, including law, as well as humanities and education. Among the administrative elite, law and some other social sciences are highly prevalent. The organizational and business elites reflect a large share of economics and business education. Education in social sciences and humanities is common in the media elite, while the natural and health sciences are strongly represented in the academic elite, but the share of social sciences and economics is relatively small. Arts and the humanities completely predominate among the cultural elite. The relatively large male presence among the academic elite is partly attributable to the privileged position of male-dominated subjects, such as technical and natural sciences, among the academic elite.

There seems to be no doubt that the educational profiles of elites broadly fit their chosen careers rather well. Members of the elites have largely chosen relevant education early in life and gone on to forge successful careers on that basis. The role of generalists, nonetheless, varies to some extent among elites. If we define generalists as persons who have made more than one career, these are far more common in politics than in other spheres, followed by administration and culture. The number of careers can be estimated on the basis of a question asking respondents to indicate if they had worked for at least two years in any of the eight different areas addressed in the elite survey. On average, the respondents had close to two careers according to this measurement. Career specialization is smallest among politicians (2.83 careers) and the cultural and administrative elites (2.06 and 2.00, respectively). Career specialization is greatest among the business elite (1.58) and rather high among the organizational, media and academic elites as well $(1.77,1.79$ and 1.72 , respectively). Despite the professionalization of politics since 1970, the data indicate that is at a lower level than among the other careers. 


\section{Network patterns}

Social networks form an important mechanism of elite power, and they may differ from one elite structure to another. Traditional elitism presupposes a single, cohesive elite with close connections across different spheres of society. Competitive elitism presupposes the centrality of plural political elites which compete for influence across different spheres. Professional pluralism is likely to be characterized by the importance of intraelite connections, but weak ties across elites. Weak ties, if there are enough of them, may nonetheless be an important resource, according to Granovetter (1973). Hence, the relative position of elites may be affected to a significant degree by their reach across elite spheres.

In analysing the network patterns of elites, we seek information which is likely to reflect how connections are structured on one hand, and how they constitute a useful resource of elite power, on the other hand. We start by studying place of residence as a rough indicator of network structures, but then move on to more direct indicators of network patterns and the importance of network connections.

\section{Residence}

Around two-thirds of the Icelandic population live in the greater Reykjavík area, which is divided into several municipalities, with the majority living in Reykjavík. The choice of residence may be indicative of lifestyle preferences, but also of the geographical dispersion of important social ties. In popular culture, there exist strong images of the lattesipping' cultural elite residing in central Reykjavík and business moguls living in spacious accommodations in the expensive suburbs of Garðabær and Seltjarnarnes.

Table 4. Residence of elite groups in 2015 (\%)

\begin{tabular}{lcccccccc}
\hline Residence & $\begin{array}{c}\text { Political } \\
\text { elite }\end{array}$ & $\begin{array}{c}\text { Administra- } \\
\text { tive elite }\end{array}$ & $\begin{array}{c}\text { Organiza- } \\
\text { tional elite }\end{array}$ & $\begin{array}{c}\text { Business } \\
\text { elite }\end{array}$ & $\begin{array}{c}\text { Media } \\
\text { elite }\end{array}$ & $\begin{array}{c}\text { Academic } \\
\text { elite }\end{array}$ & $\begin{array}{c}\text { Cultural } \\
\text { elite }\end{array}$ & Total \\
\hline $\begin{array}{l}\text { Central Reykjavík } \\
\text { Garđabær and }\end{array}$ & 22.2 & 28.5 & 15.6 & 10.2 & 45.2 & 28.0 & 61.7 & 28.5 \\
$\begin{array}{l}\text { Seltjarnarnes } \\
\text { Reykjavík }\end{array}$ & 13.0 & 10.8 & 12.5 & 33.9 & 4.8 & 10.0 & 6.4 & 13.2 \\
area other & 35.2 & 33.9 & 45.4 & 42,3 & 45.2 & 50.0 & 29.8 & 39.3 \\
Regions & 29.6 & 26.9 & 26.6 & 13.6 & 4.8 & 12.0 & 2.1 & 19.1 \\
\hline $\begin{array}{l}\text { Total } \\
\text { (N) }\end{array}$ & 100 & 100 & 100 & 100 & 100 & 100 & 100 & 100 \\
\hline & $(54)$ & $(130)$ & $(64)$ & $(59)$ & $(42)$ & $(50)$ & $(47)$ & $(446)$ \\
\hline
\end{tabular}

The cultural and media elites live almost exclusively in Reykjavík, with a clear preference for central locations. Reykjavík is very much at the centre of cultural life and media events. The business elite lives disproportionally in suburbia, with over a third in Garðabær and Seltjarnarnes. The fact that parliament, leadership of the central administration and headquarters of most organizations are in Reykjavík may provide strong opportunities for networking among the political elites. Only the political, administrative and or- 
ganizational elites live in substantial numbers outside the Reykjavík area - but even here, the regions (with roughly $1 / 3$ of the population) are underrepresented. Residence and place of work may be a relevant factor of elite integration in Iceland, but more direct information may be obtained by studying data on social interaction patterns.

\section{Social interaction}

The social world is lumpy, in the sense that contacts and connections are concentrated in places and unequal across layers and spheres of society. In fact, there is nothing particularly suspicious about such lumps. They reflect commonalities of interest and tastes as well as the practicalities of cooperation outside the structures of formal organizations. They are likely to contribute substantially to the creation of social capital (Coleman 1988). At the same time, such connections may constitute an important power resource, in the sense that they help actors produce intended effects. Contacts facilitate cooperation. Hence, for the study of power structures, it is important to learn where contact patterns lie. In the present case, we are interested in the extent to which they are focused within elite spheres and reach across such spheres.

The data on social interaction come from a question in the elite survey on social networks. What we are looking for is, on one hand, the volume of intra-elite contacts and, on the other hand, between elites. These data are presented in Graph 12.

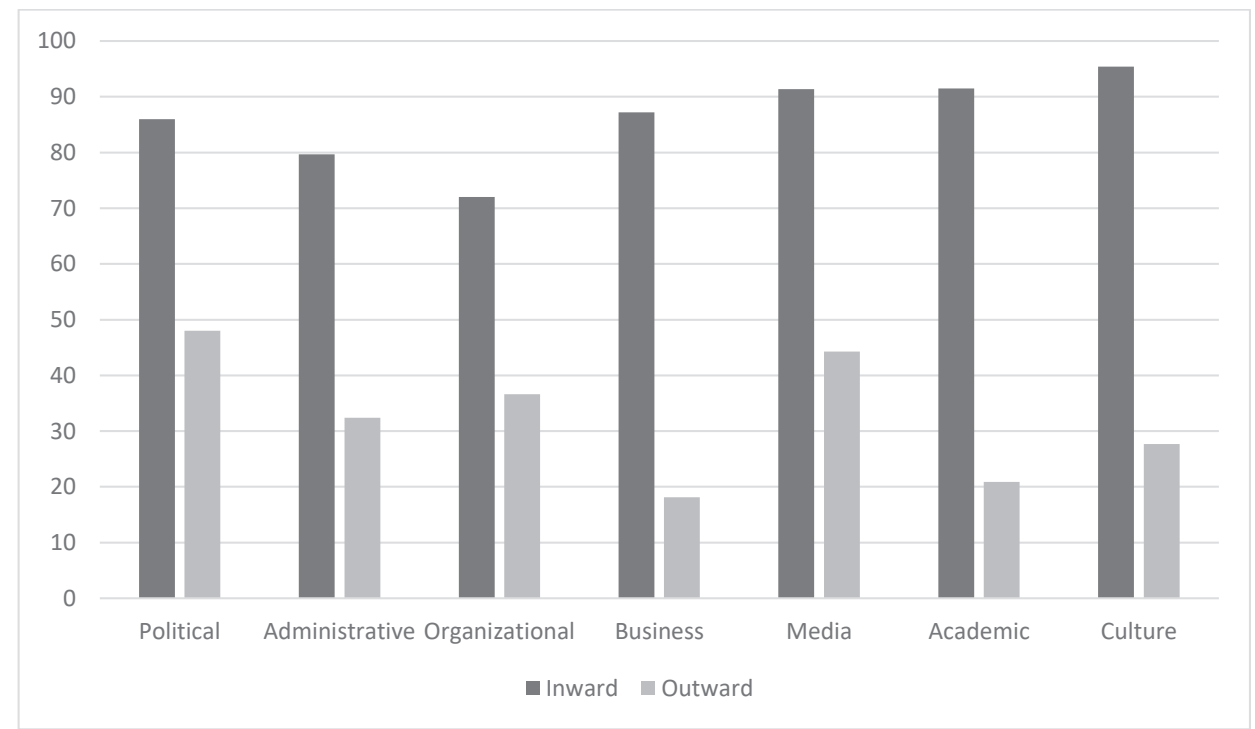

Graph 12. Network patterns: With whom elites socialize (mean [\%] inward and outward socializing ${ }^{5}$ )

The political elite is the most outward looking, followed closely by the media elite. The most inward looking are the business and academic elites, followed by the cultural elite. All elites are highly focused on their own sphere when it comes to socializing. Between 
$72 \%$ and $95 \%$ socialize very much, much or rather a lot with people from their own sector. This indicates that the elites form fairly exclusive and professionalized groups.

A different way of approaching these data is to look for significant others - other groups which the elites are most likely to socialize with. Only the organizational elite socializes more with businesspeople than others from the organizational sector, which is, of course, partly overlapping in the case of the business elite. The business elite is well-represented in the social networks of all elites, as is the academic elite. This may indicate a certain centrality of the business and academic sectors among elites, but they nonetheless weigh far less than internal elite contacts. In the case of the political elite, public administrators are the most significant external contacts.

The political elite is not centrally located, according to the data on socializing. Politicians weigh relatively little in the contact patterns of other elites. They have the greatest contacts with the organizational world and media, which is hardly surprising, given the nature of their work. They weigh least in the patterns of the academic (11\%) and cultural $(2 \%)$ elites.

Taken together, the data provide support for a professional pluralist interpretation (emphasis on intra-elite contacts), but less for competitive elitism (contacts across elites via political connections). What is still missing, however, is an evaluation of how useful the contacts are.

\section{Usefulness of connections}

Icelanders often portray their society as an arena where personal contacts and cronies are decisive in many walks of life. Statistically, however, the likelihood of random individuals knowing each other well is extremely small, even in such a small society. In traditional elitism, personal ties (especially kinship ties and other acquaintance) are likely to be highly important. In competitive elitism, political connections should be very important, while in professional pluralism, professional contacts are likely to be more important than others.

How respondents to the elite survey evaluated the usefulness of different types of contacts for their careers is shown in Graph 13. 


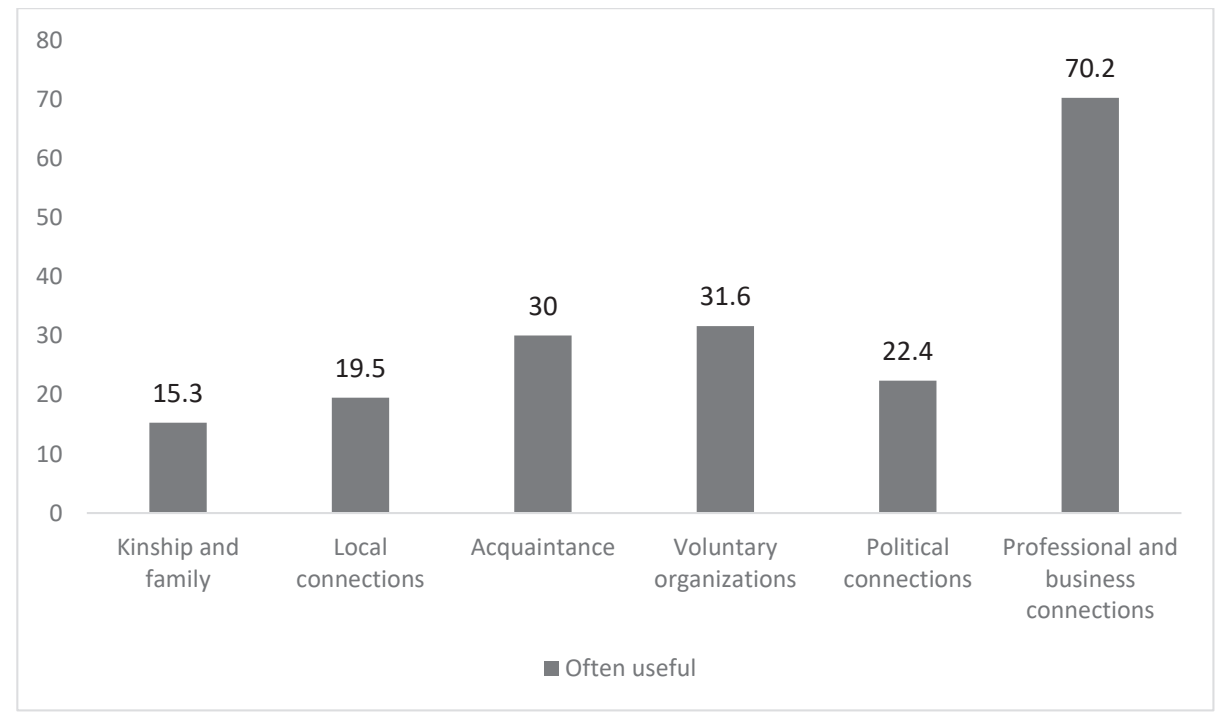

Graph 13. Network patterns: How useful do elite groups feel connections have been to their careers? All elites claiming connections to be often useful ( $\%$ of elite $)^{6}$

The general pattern is clearly that professional and business connections are of paramount importance to the elites, whereas more personalized connections, such as kinship or local ones, are less important. In between, we find general 'acquaintance' and connections from voluntary organizations. They are likely to belong to general network ties, which are part of any social structure. An interesting feature is the generally low importance of political connections, indicating that the political elite has a far weaker position in the power structure than would be expected, according to stronger versions of competitive elitism.

Table 5. Proportion of elites reporting connections to be rather often, often or very often useful (\%)

\begin{tabular}{lccccccc}
\hline & $\begin{array}{c}\text { Political } \\
\text { elite }\end{array}$ & $\begin{array}{c}\text { Administra- } \\
\text { tive elite }\end{array}$ & $\begin{array}{c}\text { Organiza- } \\
\text { tion elite }\end{array}$ & $\begin{array}{c}\text { Business } \\
\text { elite }\end{array}$ & $\begin{array}{c}\text { Media } \\
\text { elite }\end{array}$ & $\begin{array}{c}\text { Academic } \\
\text { elite }\end{array}$ & $\begin{array}{c}\text { Cultural } \\
\text { elite }\end{array}$ \\
\hline Kinship and family & 22.5 & 9.5 & 16.4 & 17.6 & 30.5 & 6.6 & 19.5 \\
Local connections & 47.9 & 14.2 & 13.4 & 19.3 & 26.4 & 7.3 & 15.0 \\
$\begin{array}{l}\text { Acquaintance } \\
\begin{array}{l}\text { Connections from vol- } \\
\text { untary organizations }\end{array}\end{array}$ & 52.8 & 28.3 & 17.5 & 17.5 & 44.4 & 19.2 & 39.2 \\
$\begin{array}{l}\text { Political connections } \\
\text { Professional and busi- }\end{array}$ & 51.1 & 10.2 & 9.6 & 19.3 & 14.3 & 5.1 & 7.9 \\
ness connections & 63.3 & 71.6 & 69.6 & 77.9 & 72.2 & 55.3 & 76.2 \\
\hline Average & 47.1 & 25.8 & 28.3 & 31.2 & 36.2 & 17.2 & 32.4 \\
\hline
\end{tabular}

Note: Figures read downwards can add up to more than $100 \%$. 
Professional and business ties are the most important ties among every elite group. Connections from voluntary organizations are important for all elite groups, although least so in the case of the academic elite, and general acquaintance is relatively important as well in all groups. Political connections are of major importance only in the case of the political elite, although they weigh more in the cases of the business and media elites than in the others. Overall, however, they are of relatively small importance.

The political elite is by far the elite which regards contacts with other elites as most valuable (47.1\% average), with the media, cultural and business elites following. These are clearly the more inter-elite network-oriented elite groups. The academic elite is the least network-oriented according to this measurement, followed by the administrative elite.

Elite evaluations of the importance of different types of contacts suggest that professional pluralism is the predominant model of elite connections, where professional and business ties are the most important ties for all elite groups. They vary, however, in the degree to which they consider contacts to other spheres to be important. The most outward-oriented of the elites is clearly the political elite, while the academic elite is least so. Yet, while the political elite considers it more important than others to reach beyond its own sphere, this gives tenuous support for competitive elitism, since other elites do not consider political connections to be particularly important. Political connections, along with kinship and local ties, are the least important contacts for other elites, suggesting that both the traditional elite model and competitive elitism are of secondary importance in elite contact networks in Iceland.

\section{Conclusion}

Traditional elitism, competitive elitism and professional pluralism have been used as models of the Icelandic power structure in the modern period. Traditional elitism, based on social exclusion and kinship ties, is seen as characteristic of the nineteenth and early twentieth centuries. It was replaced by competitive elitism with the development of modern political parties during the inter-war period. Towards the end of the twentieth century, it is hypothesized that the system became increasingly pluralistic, with the role of political parties receding as professionalism in different areas became increasingly important.

The data examined in this paper are partly historical and partly based on a survey conducted in 2015. While we find traces of traditional elitism at different periods, indicators of the predominance of kinship ties and social status in the political elite in the early twentieth century are weaker than expected, although elite privilege is clearly visible, for instance, when education variables are considered. The strongest indicator, however, of the importance of ascriptive social status relates to gender. Women were largely excluded from the political elite for most of the twentieth century.

Competitive elitism was associated with the growing role of political parties during the inter-war period, and a strong party background - suggesting party loyalty - was an important part of a political career during the second half of the twentieth century. The development of the political elite is consistent with this interpretation, but we lack data on other elites. In the early twenty-first century, a strong party background remains 
important among the political elite, although its role has weakened slightly. The relationship of the political elite to other elites, however, is less consistent with competitive elitism. According to competitive elitism, we should expect the political elite to occupy a central position - as the elite of elites - in a network stretching through different sections of society. This, however, receives scant support from our 2015 data.

In the early twenty-first century, there are two developments of considerable interest with regard to the impact of ascriptive status. On one hand, gender differences - although they remain considerable in most elites - appear to be decreasing and are probably less significant than in most other societies; on the other hand, university education has become almost a necessary condition for elite membership in most groups. This, however, goes hand in hand with a steep increase in university education in society at large, which means that despite the importance of university education, the elites are not as exclusive with regard to education as before. The growing importance of university education among elite groups might be interpreted as compatible with either a model of social distinction or professional achievement. In the context of the greater availability of university education, a weaker status system and increasing importance of professional criteria in many spheres of society, however, the latter interpretations seem more plausible.

Professional pluralism is associated with the prevalence of distinct elites in different enclaves of society, and the absence of a dominant elite or close interconnections across the elite structure. This seems to characterize the modern-day power structure in Iceland. There are indeed strong professional elites in different spheres, but they remain relatively open and recruited on the basis of merit or professional criteria. Even the political elite has become professionalized to an increasing extent since the 1970s. But the growth of professionalized pluralism is not necessarily an egalitarian trend in all respects. It relies on merit criteria for elite selection, such as education, which are closely related to social and economic status and inevitably exclude those with weaker credentials. Moreover, while gender differences may be expected to recede as the role of merit increases, the system is still gender-biased.

Despite the relatively encouraging findings of this review of the Icelandic power structure, there are important caveats which need to be taken into consideration. The elite approach to power is informative concerning some aspects of the power structure, but hardly tells the whole story. It is concerned with power resources and the groups with privileged access to them. However, it falls short - at least in the present version - of studying the actual exercise of power, how the decision-making agenda is shaped or how influencing people's minds may affect outcomes. The rules of the game and the participants' ideas about its nature may be skewed in various ways, even if elite structures are open and pluralistic. Business may, for example, enjoy a privileged status in relation to other interests, because of some pre-conceived ideas about its ultimate importance (Lindblom 1977). In the Icelandic case, there is reason to believe that well-established interests associated with the primary economy have privileged access to power, even if this is in no way observable through the composition of political elites. Having said that, an open, pluralistic and meritocratic elite structure is something which most theorists are likely to prefer to closed, elitist and privileged ones. 


\section{Notes}

1 An important limitation of the historical data is that only one elite is observed and the focus on the political aspects of Icelandic elitism is therefore relatively great. Lack of resources prevent us from including more elites in this part of the investigation. A more theoretically oriented justification, however, is that most authors writing on the subject have strongly emphasized the centrality of political elites.

2 Education was measured on a scale where low education $=0$, intermediary $=0.5$ and high $=1$. The graph shows means for each group.

3 Information on education of population at large obtained from Statistics Iceland, courtesy of Ómar Harðarson. The data is published on the understanding that it is incomplete and may contain inaccuracies.

4 The SDA includes the Social Democratic Party, People’s Alliance, Djóðvaki, Bandalag jafnaðarmanna. Non-attached elite members are not represented in the graph for the sake of simplicity but they constitute $7.8 \%$ of the political elite, $59.2 \%$ of the administrative elite, $38.3 \%$ of the organizational elite, $50.8 \%$ of the business elite, $65 \%$ of the media elite, $63 \%$ of the academic elite and $52 \%$ of the cultural elite.

5 The means show $\%$ of respondents claiming to socialize very much, much or rather a lot with group. Inward refers to \% socializing with people in same sphere (e.g. \% of political elite socializing with people in politics) while outward refers to mean \% claiming to socialize much with people in the other spheres.

6 'Often' refers to the \% of respondents saying 'rather often', 'often' and 'very often'.

\section{References}

Best, H., and Higley J. (2010). Democratic Elitism. New Theoretical and Comparative Perspectives. Leiden: Brill. Christiansen, P., Møller, B., and Togeby L. (2001). Den Danske Elite. København: Hans Reitzels Forlag.

Coleman, J. (1988). "Social Capital in the Creation of Human Capital", The American Journal of Sociology 94, 95-120.

Cornell, A., and Lapuente, V. (2014). "Meritocratic Administration and Democratic Stability", Journal of Democratization 21(7), 1286-1304.

Corbett, J. (2013). "Everybody Knows Everybody: Practicing Politics in the Pacific Islands", Democratization 22(1), 51-72.

Dahl, R. (1961). Who governs?. New Haven: Yale University Press.

Dahlström, C., Peters, B.G., and Pierre, J. Steering from the Centre. Toronto: University of Toronto Press.

Dowding, K. (1996). Power. Minneapolis: University of Minnesota Press.

Dunleavy, P., and O'Leary, B. 1987. Theories of the State. London: Macmillan.

Erlingsson, G., Linde, J., and Öhrvall, R. (2016). "Distrust in Utopia? Public Perceptions of Corruption and Political Support in Iceland Before and After the financial Crisis of 2008", Government and Opposition 51(4), 553-579.

Granovetter, M. (1973). “The Strength of Weak ties”, American Journal of Sociology 78(6), 1360-1380.

Grímsson, Ó.R. (1976). “The Icelandic Power Structure 1800-2000”, Scandinavian Political Studies 11, 9-33.

Guðmundsson, H. (1979). Uppruni Sjálfstaðisflokkesins. Reykjavík: Félagsvísindadeild and Örn \& Örlygur. Held, D. (1996). Models of Democracy (2nd ed.). Cambridge: Polity.

Higley, J., and Pakulski, J. (2012). "Elites, Elitism and Elite Theory: Unending Confusion?”. Retrived from http://paperroom.ipsa.org/papers/paper_11235.pdf

Hoffmann-Lange, U. (2006). Methodological Developments in Elite Research. Paper for presentation at the 20th IPSA World Congress „Is Democracy Working?“. Fukuoka, Japan July 9-14, 2006.

Indriðason, I.H. (2005). "A Theory of Coalitions and Clientelism: Coalition Politics in Iceland. 19452000", European Journal of Political Research 44(3), 439-464. 
Jónsson, G. (2014). "Iceland and the Nordic Model of Consensus Democracy", Scandinavian Journal of History 39(4), 510-528.

Kopecky, P., and Mair, P. (2012). "Conclusion: Party Patronage in Contemporary Europe", in P. Kopecky. P. Mair and M. Spirova (eds.), Party Patronage and Party Government in European Democracies (pp. 196-205). Oxford: Oxford University Press.

Kristinsson, G.H. (1993). "Valdakerfið fram til Viðreisnar", in G. Hálfdánarson and S. Kristjánsson (eds.), Íslensk pjóđfélagspróun 1880-1990: Ritgerdir (pp. 321-354). Reykjavík: Félagsvísindastofnun and Sagnfræðistofnun.

Kristinsson, G.H. (1994). Embattismenn og stjórnmálamenn. Skipulag og vinnubrögd $i$ islenskeri stjórnsíshu. Reykjavík: Heimskringla.

Kristinsson, G.H. (1996). "Parties. States and Patronage”, West European Politics 19(3), 433-457.

Kristinsson, G.H. (2012). "Party Patronage in Iceland: Rewards and Control Appointments", in P. Kopecky, P. Mair and M. Spirova (eds.), Party Patronage and Party Government in European Democracies (pp. 186-205). Oxford: Oxford University Press.

Kristinsson, G.H. (2014). Hin mörgu andlit lyoradis. Reykjavík: University of Iceland Press.

Kristinsson, G.H., and Indriðason, I.H. (2007). "Stjórnsækni og stefnufesta”, Stjórnmál \& stjórnsýsla 4(1), 89-111.

Kristjánsson, S. (1993). “Stjórnmálaflokkar. ríkisvald og samfélag 1959-1990”, in G. Hálfdánarson and Svanur Kristjánsson (eds.). Íslensk pjódfélagspróun 1880-1990: Ritgerdir (pp. 355-398). Reykjavík: Félagsvísindastofnun and Sagnfræðistofnun.

Kristjánsson, S. (1994). Frá flokksrađi til persónustjórnmála. Fjórflokekarnir 1959-1991. Reykjavík: Félagsvísindastofnun Háskóla Íslands.

Lindblom, C. (1977). Politics and Markets. New York: Basic Books.

Lukes, S. (1974). Power. A Radical View. London: Macmillan.

Michels, R. (1962). Political Parties: a Sociological Study of the Oligarchical Tendencies of Modern Democracy. New York: The Free Press.

Mosca, G. (1939). The Ruling Class. New York: McGraw-Hill.

Nordal, J. (1994). Málsefni. Reykjavík: Hið íslenzka bókmenntafélag.

Pareto, V. (1961). "The Circulation of Elites", in T. Parsons (ed.), Theories of Society; Foundations of Modern Sociological Theory (pp. 551-8). New York: The Free Press.

Peters, B., and Pierre, J. (2004). Politicization of the Civil Service in Comparative Perspective. London: Routledge.

Petersson, O., Hirdman, Y., Persson, I., and Olsen, J. (1990). Demokrati och Makt i Sverige. Stockholm: SOU.

Putnam, R. (1977). "Elite Transformation in Advanced Industrial Societies. An Empirical Assessment of the Theory of Technocracy", Comparative Political Studies 10(3), 383-412.

Ruostetsaari, I. (2007). "Nordic Elites in Comparative Perspective", Comparative Sociology 6, 158-189.

Russel, B. (1938). Power: A New Social Analysis. London: Allen \& Unwin.

Schumpeter, J. (1976). Capitalism, Socialism and Democracy. London: George Allen \& Unwin.

Shefter, M. (1974). Political Parties and the State. The American Historical Experience. Princeton: Princeton University Press.

Torfason, M., Einarsdóttir, P., Rafnsdóttir, G., and Sigurðardóttir, M. (2017). "Elítur á Íslandi - einsleitni og innbyrðis tengsl", Stjórnmál \& stjórnsýsla 13(1), 1-26.

Vibert, F. (2007). The Rise of the Unelected. Cambridge: Cambridge University Press.

Vilhelmsdóttir, S., and Kristinsson, G.H. (2015). Legitimacy and Democracy in Iceland: Before and After the Crash. Conference on "Workings of Democracy. Practices. Norms and Understanding". University of Iceland, Reykjavík May 27-29, 2015.

Weber, M. (1968). Economy and Society. Berkley: University of California Press.

World Economic Forum (2016). The Global Gender Gap Report 2016. Retrieved from http:/ /www3.weforum.org/docs/GGGR16/WEF_Global_Gender_Gap_Report_2016.pdf

Wrong, D. (1995). Power: Its forms. bases and uses. London: Transaction Publishers.

Østerud, Ø., Engelstad, F., and Selle, P. (2004). Makten og Demokratiet. Oslo: Gyldendahl Akademisk. 


\section{Appendix}

Table A1. Ascriptive social status of MPs: Paternal education (\%)

\begin{tabular}{lcccccc}
\hline & 1917 & 1949 & 1965 & 1988 & 2004 & 2016 \\
\hline Low & 62 & 65 & 52 & 44 & 18 & 17 \\
Intermediary & 13 & 21 & 35 & 44 & 57 & 46 \\
High & 25 & 14 & 13 & 11 & 25 & 37 \\
\hline Total & 100 & 100 & 100 & 100 & 100 & 100 \\
(N) & $(40)$ & $(52)$ & $(50)$ & $(63)$ & $(61)$ & $(63)$ \\
\hline
\end{tabular}

Note: Low means elementary school or less. High means university education. All others are intermediary.

Table A2. Ascriptive social status of elites 2015: Paternal education (\%)

\begin{tabular}{lcccc}
\hline & Low & Intermediary & High & Total \\
\hline Politicians & 18.0 & 46.0 & 36.0 & 100.0 \\
Administrators & 19.5 & 46.3 & 34.1 & 100.0 \\
Organizations & 35.7 & 37.5 & 26.8 & 100.0 \\
Business & 24.1 & 53.5 & 22.4 & 100.0 \\
Media & 17.5 & 37.5 & 45.0 & 100.0 \\
Academia & 23.4 & 29.8 & 46.8 & 100.0 \\
Culture & 25.6 & 30.3 & 44.2 & 100.0 \\
\hline Total & 23.0 & 41.7 & 35.3 & 100.0 \\
(N) & $(96)$ & $(178)$ & $(147)$ & $(417)$ \\
\hline
\end{tabular}

Table A3. Gender of MPs, 1917-2016 (\%)

\begin{tabular}{lccccccc}
\hline & \multicolumn{7}{c}{ Research year } \\
\cline { 2 - 6 } Gender & 1917 & 1949 & 1965 & 1988 & 2004 & 2016 & Total \\
\hline Male & 100.0 & 98.1 & 98.3 & 79.4 & 68.3 & 52.4 & 80.9 \\
Female & 0.0 & 1.9 & 1.7 & 20.6 & 31.7 & 47.6 & 19.1 \\
\hline Total & 100.0 & 100.0 & 100.0 & 100.0 & 100.0 & 100.0 & 100.0 \\
(N) & $(40)$ & $(51)$ & $(60)$ & $(63)$ & $(63)$ & $(63)$ & $(341)$ \\
\hline
\end{tabular}

Table A4. Gender composition of Icelandic elites in 2015 (\%)

\begin{tabular}{lccccccccc}
\hline & \multicolumn{7}{c}{ Elite groups } & \\
\cline { 2 - 7 } Gender & Political & $\begin{array}{c}\text { Adminis- } \\
\text { trative }\end{array}$ & $\begin{array}{c}\text { Organiza- } \\
\text { tional }\end{array}$ & Business & Media & Academic & Cultural & Total \\
\hline Male & 57.4 & 62.3 & 64.1 & 77.4 & 64.3 & 70.6 & 58.0 & 64.7 \\
Female & 42.6 & 37.7 & 35.9 & 22.6 & 35.7 & 29.4 & 42.0 & 35.3 \\
\hline Total & 100 & 100 & 100 & 100 & 100 & 100 & 100 & 100 \\
(N) & $(54)$ & $(130)$ & $(64)$ & $(62)$ & $(42)$ & $(51)$ & $(50)$ & $(453)$ \\
\hline
\end{tabular}


Table A5. Proportion of MPs with parents with parliamentary experience (\%)

\begin{tabular}{lccccccc}
\hline & \multicolumn{7}{c}{ Research year } \\
\cline { 2 - 7 } Parents with parliamentary experience & 1917 & 1949 & 1965 & 1988 & 2004 & 2016 & Total \\
\hline No & 90.0 & 92.3 & 95.0 & 90.5 & 92.1 & 93.7 & 92.4 \\
Yes & 10.0 & 7.7 & 5.0 & 9.5 & 7.9 & 6.3 & 7.6 \\
\hline Total & 100 & 100 & 100 & 100 & 100 & 100 & 100 \\
(N) & $(40)$ & $(52)$ & $(60)$ & $(63)$ & $(63)$ & $(63)$ & $(341)$ \\
\hline
\end{tabular}

Table A6. Education of MPs, 1917-2016 (\%)

\begin{tabular}{lccccccc}
\hline & \multicolumn{7}{c}{ Research year } \\
\cline { 2 - 6 } Education of MPs & 1917 & 1949 & 1965 & 1988 & 2004 & 2016 & Total \\
\hline Elementary school or less & 19.4 & 10.6 & 10.3 & 4.8 & 6.6 & 4.8 & 8.6 \\
Intermediary & 33.3 & 38.3 & 41.4 & 46.8 & 32.3 & 16.1 & 33.6 \\
University & 33.3 & 31.9 & 34.5 & 27.4 & 41.0 & 41.3 & 35.2 \\
University post-graduate & 13.9 & 19.1 & 13.8 & 21.0 & 19.7 & 42.9 & 22.6 \\
\hline Total & 100 & 100 & 100 & 100 & 100 & 100 & 100 \\
(N) & $(36)$ & $(47)$ & $(58)$ & $(62)$ & $(61)$ & $(63)$ & $(327)$ \\
\hline
\end{tabular}

Table A7. Self-reported education of elites according to the 2015 survey (\%)

\begin{tabular}{lcccccccc}
\hline & \multicolumn{7}{c}{ Elite groups } \\
\cline { 2 - 8 } $\begin{array}{l}\text { Self-reported } \\
\text { education }\end{array}$ & Political & $\begin{array}{c}\text { Adminis- } \\
\text { trative }\end{array}$ & $\begin{array}{c}\text { Organi- } \\
\text { zational }\end{array}$ & Business & Media & Academic & Cultural & Total \\
\hline Elementary school & 3.9 & 0.0 & 6.9 & 3.4 & 5.0 & 0.0 & 0.0 & 2.4 \\
Intermediary & 9.8 & 0.8 & 20.7 & 6.8 & 10.4 & 0.0 & 8.9 & 7.1 \\
University & 86.3 & 99.2 & 72.4 & 89.8 & 85.0 & 100.0 & 91.1 & 90.6 \\
\hline Total & 100 & 100 & 100 & 100 & 100 & 100 & 100 & 100 \\
(N) & $(51)$ & $(124)$ & $(58)$ & $(59)$ & $(40)$ & $(48)$ & $(45)$ & $(425)$ \\
\hline
\end{tabular}

Table A8. Proportion of MPs with a background in party work and local government prior to entering parliament (\%)

\begin{tabular}{lcccccc}
\hline & 1917 & 1949 & 1965 & 1988 & 2004 & 2016 \\
\hline No background known & 42.5 & 46.2 & 28.3 & 15.9 & 17.5 & 28.6 \\
Background in local government & 55.0 & 51.9 & 51.7 & 46.0 & 44.4 & 44.4 \\
Representative roles in party organization & 2.5 & 11.5 & 38.4 & 74.6 & 64.9 & 65.1 \\
\hline Total & 100 & 100 & 100 & 100 & 100 & 100 \\
(N) & $(40)$ & $(52)$ & $(60)$ & $(63)$ & $(63)$ & $(63)$ \\
\hline
\end{tabular}


Table A9. Elite connections to political parties (\% of all elites who are/have been attached to parties)

\begin{tabular}{lcccccc}
\hline & $\begin{array}{c}\text { Non-attached to } \\
\text { political parties }\end{array}$ & $\begin{array}{c}\text { Non-active party } \\
\text { members }\end{array}$ & $\begin{array}{c}\text { Active party } \\
\text { members }\end{array}$ & $\begin{array}{c}\text { Leading } \\
\text { positions }\end{array}$ & Total & N \\
\hline Political elite & 7.7 & 5.8 & 11.5 & 75.0 & 100.0 & 52 \\
Administrative elite & 55.1 & 27.6 & 5.5 & 11.8 & 100.0 & 127 \\
Organizational elite & 43.3 & 23.3 & 13.3 & 20.0 & 100.0 & 60 \\
Business elite & 48.3 & 26.7 & 6.7 & 18.3 & 100.0 & 60 \\
Media elite & 63.4 & 17.0 & 12.2 & 7.3 & 100.0 & 41 \\
Academic elite & 60.4 & 22.9 & 8.3 & 8.3 & 100.0 & 48 \\
Cultural elite & 52.2 & 37.0 & 8.7 & 2.2 & 100.0 & 46 \\
\hline All elites & 47.9 & 23.7 & 8.8 & 19.6 & 100.0 & 434 \\
\hline
\end{tabular}

Table A10. Elite connections to political parties (\% of elites who are/have been party members)

\begin{tabular}{lccccc}
\hline & $\begin{array}{c}\text { Independence } \\
\text { Party }\end{array}$ & $\begin{array}{c}\text { Progressive } \\
\text { Party }\end{array}$ & $\begin{array}{c}\text { Social Demo- } \\
\text { cratic Alliance }\end{array}$ & Left Greens & Others \\
\hline Political elite & 31.9 & 27.7 & 23.4 & 12.8 & 14.9 \\
Administrative elite & 56.9 & 10.3 & 34.5 & 1.7 & 1.7 \\
Organizational elite & 59.5 & 10.8 & 35.1 & 10.8 & 5.4 \\
Business elite & 76.7 & 16.7 & 10.0 & 0.0 & 0.0 \\
Media elite & 40.0 & 13.3 & 46.7 & 13.3 & 6.7 \\
Academic elite & 38.9 & 5.6 & 44.4 & 16.7 & 11.1 \\
Cultural elite & 22.7 & 0 & 77.3 & 50.0 & 18.2 \\
\hline All elites & 48.9 & 13.7 & 34.8 & 11.9 & 7.5 \\
\hline
\end{tabular}

Note: SDA includes the Social Democratic Party, People's Alliance, bjóðvaki and Bandalag jafnaðarmanna. Figures add up to more than $100 \%$ because some have been members of more than one party.

Table A11. Mean number of careers among elite respondents

\begin{tabular}{lccc}
\hline Elite groups & $\mathrm{M}$ & $\mathrm{SD}$ & $\mathrm{N}$ \\
\hline Political & 2.83 & 1.410 & 52 \\
Administrative & 2.00 & 1.064 & 130 \\
Organizational & 1.77 & 1.123 & 64 \\
Business & 1.58 & 1.095 & 62 \\
Media & 1.79 & 1.138 & 42 \\
Academic & 1.72 & 1.161 & 50 \\
Cultural & 2.06 & 1.126 & 49 \\
\hline Total & 1.96 & 1.191 & 449 \\
\hline
\end{tabular}


Table A12. With whom the elites socialize (\% who socialize very much, much or rather a lot with group)

\begin{tabular}{lccccccc}
\hline & $\begin{array}{c}\text { Political } \\
\text { elite }\end{array}$ & $\begin{array}{c}\text { Administra- } \\
\text { tive elite }\end{array}$ & $\begin{array}{c}\text { Organiza- } \\
\text { tion elite }\end{array}$ & $\begin{array}{c}\text { Business } \\
\text { elite }\end{array}$ & $\begin{array}{c}\text { Media } \\
\text { elite }\end{array}$ & $\begin{array}{c}\text { Academic } \\
\text { elite }\end{array}$ & $\begin{array}{c}\text { Cultural } \\
\text { elite }\end{array}$ \\
\hline Politicians & 86.0 & 26.0 & 31.6 & 18.9 & 30.6 & 10.7 & 2.3 \\
Public administrators & 66.0 & 79.7 & 40.4 & 18.9 & 30.6 & 31.7 & 22.8 \\
Organizational people & 48.0 & 34.2 & 72.0 & 18.9 & 25.0 & 12.8 & 29.5 \\
Business people & 52.0 & 46.3 & 79.0 & 87.2 & 61.1 & 25.6 & 27.2 \\
Media people & 38.0 & 18.8 & 22.8 & 13.7 & 91.4 & 14.9 & 31.8 \\
Academics & 48.0 & 46.3 & 33.4 & 25.8 & 27.8 & 91.5 & 52.3 \\
Culture and arts & 36.0 & 22.8 & 12.3 & 12.1 & 61.1 & 29.9 & 95.4 \\
\hline
\end{tabular}

Table A13. How useful do you feel the following social connections have been to your career? All elites (\%)

\begin{tabular}{lcccccc}
\hline & $\begin{array}{c}\text { Kinship and } \\
\text { family }\end{array}$ & $\begin{array}{c}\text { Acquain- } \\
\text { tance }\end{array}$ & $\begin{array}{c}\text { Connections } \\
\text { from voluntary } \\
\text { organizations }\end{array}$ & $\begin{array}{c}\text { Professional } \\
\text { and business } \\
\text { connections }\end{array}$ & $\begin{array}{c}\text { Political c } \\
\text { onnections }\end{array}$ & $\begin{array}{c}\text { Local } \\
\text { connections }\end{array}$ \\
\hline Very seldom & 42.0 & 22.7 & 28.6 & 7.6 & 50.6 & 40.0 \\
Seldom & 19.3 & 15.6 & 14.3 & 4.4 & 12.1 & 16.1 \\
Rather seldom & 9.3 & 14.9 & 8.2 & 5.9 & 6.5 & 11.7 \\
Neither nor & 14.3 & 16.8 & 17.6 & 12.2 & 14.4 & 12.7 \\
Rather often & 6.0 & 15.1 & 16.8 & 23.8 & 10.5 & 11.7 \\
Often & 4.8 & 9.0 & 12.2 & 25.9 & 4.0 & 4.4 \\
Very often & 4.5 & 5.9 & 2.6 & 20.5 & 7.9 & 3.4 \\
\hline Total & 100.0 & 100.0 & 100.0 & 100.0 & 100.0 & 100.0 \\
\hline
\end{tabular}


Table A14. Women in elite groups (\%)

\begin{tabular}{|c|c|c|c|c|c|}
\hline & Age & Male & Female & Total & $\mathrm{N}$ \\
\hline \multirow[t]{3}{*}{ Political elite } & $20-49$ & 53.3 & 46,7 & 100.0 & 30 \\
\hline & $50-59$ & 41.7 & 52.9 & 100.0 & 17 \\
\hline & 60 or older & 100.0 & 0 & 100.0 & 7 \\
\hline \multirow[t]{3}{*}{ Administrative elite } & $20-49$ & 36.7 & 63.3 & 100.0 & 30 \\
\hline & $50-59$ & 55.1 & 44.9 & 100.0 & 49 \\
\hline & 60 or older & 84.3 & 15.7 & 100.0 & 51 \\
\hline \multirow[t]{3}{*}{ Organizational elite } & $20-49$ & 44.4 & 55.6 & 100.0 & 18 \\
\hline & $50-59$ & 66.7 & 33.3 & 100.0 & 30 \\
\hline & 60 or older & 81.3 & 18.8 & 100.0 & 16 \\
\hline \multirow[t]{3}{*}{ Business elite } & $20-49$ & 54.2 & 45.8 & 100.0 & 24 \\
\hline & $50-59$ & 86.4 & 13.6 & 100.0 & 22 \\
\hline & 60 or older & 100.0 & 0 & 100.0 & 16 \\
\hline \multirow[t]{3}{*}{ Media elite } & $20-49$ & 50.0 & 50.0 & 100.0 & 22 \\
\hline & $50-59$ & 90.0 & 10.0 & 100.0 & 10 \\
\hline & 60 or older & 70.0 & 30.0 & 100.0 & 10 \\
\hline \multirow[t]{3}{*}{ Academic elite } & $20-49$ & 54.5 & 45.5 & 100.0 & 11 \\
\hline & $50-59$ & 83.3 & 16.7 & 100.0 & 18 \\
\hline & 60 or older & 68.2 & 31.8 & 100.0 & 22 \\
\hline \multirow[t]{3}{*}{ Cultural elite } & $20-49$ & 41.7 & 58.3 & 100.0 & 24 \\
\hline & $50-59$ & 75.0 & 25.0 & 100.0 & 16 \\
\hline & 60 or older & 70.0 & 30.0 & 100.0 & 10 \\
\hline
\end{tabular}

Table A15. Percentage of elites who have been party members

\begin{tabular}{lccccccc}
\hline & Pol & Adm & Org & Bus & Media & Acad & Cult \\
\hline No party & 7.8 & 59.2 & 38.3 & 50.8 & 65.0 & 63.0 & 52.1 \\
SDA & 19.5 & 10.9 & 17.8 & 4.8 & 13.6 & 14.8 & 17.9 \\
LG & 10.6 & 0.7 & 5.5 & 0.0 & 3.9 & 5.6 & 10.6 \\
PP & 23.1 & 3.6 & 6.9 & 8.0 & 3.9 & 1.8 & 2.4 \\
IP & 26.6 & 20.4 & 31.5 & 36.5 & 11.7 & 13.0 & 5.7 \\
Others & 12.4 & 5.1 & 0.0 & 0.0 & 1.9 & 1.8 & 11.4 \\
\hline Total & 100.0 & 100.0 & 100.0 & 100.0 & 100.0 & 100.0 & 100.0 \\
\hline
\end{tabular}

Note: The \% of non-party members is based on a question on party membership, while the division among parties is based on a weighted estimate of the share of different parties (some have been members of more than one party). 
Table A16. Education of Icelandic elites in 2015 according to subject area (\% of elites who have studied subjects)

\begin{tabular}{lcccccccc}
\hline & $\begin{array}{c}\text { Political } \\
\text { elite }\end{array}$ & $\begin{array}{c}\text { Administra- } \\
\text { tive elite }\end{array}$ & $\begin{array}{c}\text { Organiza- } \\
\text { tional elite }\end{array}$ & $\begin{array}{c}\text { Business } \\
\text { elite }\end{array}$ & $\begin{array}{c}\text { Media } \\
\text { elite }\end{array}$ & $\begin{array}{c}\text { Academic } \\
\text { elite }\end{array}$ & $\begin{array}{c}\text { Cultural } \\
\text { elite }\end{array}$ & Total \\
\hline Arts & 4.4 & 0.8 & 7.0 & 3.8 & 8.3 & 4.2 & 71.4 & 11.1 \\
Humanities & 22.2 & 13.1 & 11.6 & 0.0 & 44.4 & 16.7 & 47.6 & 19.3 \\
Technical & 6.7 & 12.3 & 9.3 & 17.0 & 2.8 & 0.0 & 0.0 & 10.0 \\
Agricultural & 4.4 & 4.9 & 2.3 & 1.9 & 0.0 & 2.1 & 0.0 & 2.8 \\
Educational & 17.8 & 7.4 & 14.0 & 5.7 & 2.8 & 18.8 & 4.8 & 9.8 \\
Natural sciences & 2.2 & 12.3 & 4.7 & 5.7 & 5.6 & 35.4 & 0.0 & 10.3 \\
Health & 6.7 & 10.7 & 7.0 & 0.0 & 0.0 & 25.0 & 0.0 & 8.0 \\
Economics and & 28.9 & 20.5 & 55.8 & 71.7 & 22.2 & 12.5 & 7.1 & 30.1 \\
business & 24.4 & 18.9 & 11.6 & 3.8 & 55.6 & 14.6 & 9.5 & 18.5 \\
Social & 20.0 & 40.2 & 11.6 & 15.1 & 0.0 & 4.2 & 0.0 & 18.8 \\
Law & - & - & - & 1.9 & - & - & - & 0.3 \\
Personal services & 2.2 & 5.0 & 0.0 & 1.9 & 2.9 & 0.0 & 0.0 & 2.3 \\
Security & 2.0 & & & & & & & \\
\end{tabular}

Note: Figures add up to more than $100 \%$ because many respondents have studied more than one subject. 